\title{
Dinuclear Au(ı) N-heterocyclic carbene complexes derived from unsymmetrical azolium cyclophane salts: potential probes for live cell imaging applications $\uparrow$
}

Received 12th April 2016, Accepted 3rd July 2016

DOI: $10.1039 / \mathrm{c} 6 \mathrm{dt} 01409 \mathrm{~g}$

www.rsc.org/dalton
Louise E. Wedlock, ${ }^{\text {a,b }}$ Peter J. Barnard, ${ }^{\text {a,c }}$ Aleksandra Filipovska, ${ }^{\text {a,d }}$ Brian W. Skelton, ${ }^{\text {a,e }}$ Susan J. Berners-Price ${ }^{\star a, b}$ and Murray V. Baker ${ }^{\star a, f}$

We have synthesized a new series of azolium cyclophanes and used them as precursors of inherently luminescent dinuclear $\mathrm{Au}(\mathrm{I})-\mathrm{N}$-heterocyclic carbene (NHC) complexes. The azolium cyclophanes contained two azolium groups (either imidazolium or benzimidazolium), an o-xylyl group, and an alkyl linker chain (either $\mathrm{C}_{2}, \mathrm{C}_{3}$ or $\mathrm{C}_{4}$ ). All of the azolium cyclophanes were characterised by $\mathrm{X}$-ray diffraction studies and VT NMR studies, and all were fluxional in solution on the NMR timescale. The $\mathrm{C}_{3}-$ and $\mathrm{C}_{4}$-linked azolium cyclophanes served as precursors of $\mathrm{Au}_{2} \mathrm{~L}_{2}{ }^{2+}$ complexes ( $\mathrm{L}$ is a cyclophane bis(NHC) ligand). Due to the unsymmetrical nature of the azolium cyclophanes, the $\mathrm{Au}_{2} \mathrm{~L}_{2}{ }^{2+}$ complexes each existed as cis and trans isomers. X-ray diffraction studies showed that the $\mathrm{Au}_{2} \mathrm{~L}_{2}{ }^{2+}$ complexes had short intramolecular Au...Au distances, in the range 2.9-3.3 $\AA$, suggestive of an aurophilic attraction, presumably as a consequence of the geometrical constraints imposed by the cyclophane bis(NHC) ligands. The complexes having the shortest $\mathrm{Au}$...Au distances (i.e., those based on $\mathrm{C}_{3}$-linked cyclophanes) exhibited intense luminescence in solution. The uptake of one of the dinuclear Au-NHC complexes by tumorigenic cells, and its subsequent distribution and toxicity in the cells, was monitored by luminescence microscopy over $6 \mathrm{~h}$ and proliferation measurements, respectively.

\section{Introduction}

Cyclophanes have been of significant interest during the last decade, spurred on by studies into their interesting conformational behaviour, ${ }^{1-6}$ their application for anion recognition, ${ }^{4,7-10}$ and in the case of azolium cyclophanes, for their use as precursors to N-heterocyclic carbene (NHC) metal complexes. ${ }^{5,11-21}$ In recent years there has been a high level of

\footnotetext{
${ }^{a}$ School of Chemistry and Biochemistry M310, The University of Western Australia, Perth,WA 6009, Australia. E-mail: murray.baker@uwa.edu.au

${ }^{b}$ Institute for Glycomics, Griffith University, Gold Coast Campus, QLD 4222, Australia.E-mail: s.berners-price@griffith.edu.au

${ }^{c}$ Department of Chemistry, La Trobe Institute for Molecular Science, La Trobe University, Bundoora, VIC 3086, Australia

${ }^{d}$ Harry Perkins Institute of Medical Research, QEII Medical Centre, Nedlands, WA 6009, Australia

${ }^{e}$ Centre for Microscopy, Characterisation, and Analysis M310, The University of Western Australia, Perth, WA 6009, Australia

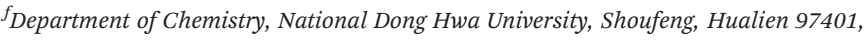
Taiwan, $R O C$

$\dagger$ Electronic supplementary information (ESI) available. CCDC 834016-834025. For ESI and crystallographic data in CIF or other electronic format see DOI: 10.1039/c6dt01409g
}

interest in the antitumour properties of $\mathrm{Au}(\mathrm{I})-\mathrm{NHC}$ complexes. ${ }^{22,23}$ In an early study in this area, we showed that some $\mathrm{Au}(\mathrm{I})$-NHC complexes were toxic to tumour cells, but not to normal cells, and selectivity for tumour cells could be achieved by fine-tuning the hydrophilic/lipophilic balance through ligand design. ${ }^{24} \mathrm{~A}$ mechanism of action involving selective inhibition of thioredoxin reductase (TrxR) in mitochondria of tumour cells has been proposed. ${ }^{24,25}$ To this end, we have also reported a series of related lipophilic, cationic, dinuclear $\mathrm{Au}(\mathrm{I})$ complexes containing bridging bidentate NHC ligands derived from azolium-linked cyclophanes. ${ }^{13,26,27}$

$\mathrm{Au}(\mathrm{I}) \cdots \mathrm{Au}(\mathrm{I})$ distances that are less than the sum of the van der Waals radii for the $\mathrm{Au}(\mathrm{I})$ ions are known to be weakly attractive, and such aurophilic interactions have been the subject of much attention in the scientific community. ${ }^{28-32}$ Remarkable photophysical behaviour is often associated with compounds containing short $\mathrm{Au}(\mathrm{I}) \cdots \mathrm{Au}(\mathrm{I})$ contacts, ${ }^{33-38}$ a feature that has made them an important family of luminescent metal complexes, from both an experimental and theoretical perspective. $^{30,32}$ Previously, we have shown that for a family of dinuclear $\mathrm{Au}-\mathrm{NHC}$ complexes where the NHC groups are part of a cyclophane framework, modification of the supporting cyclophane framework afforded control of the intramolecular 


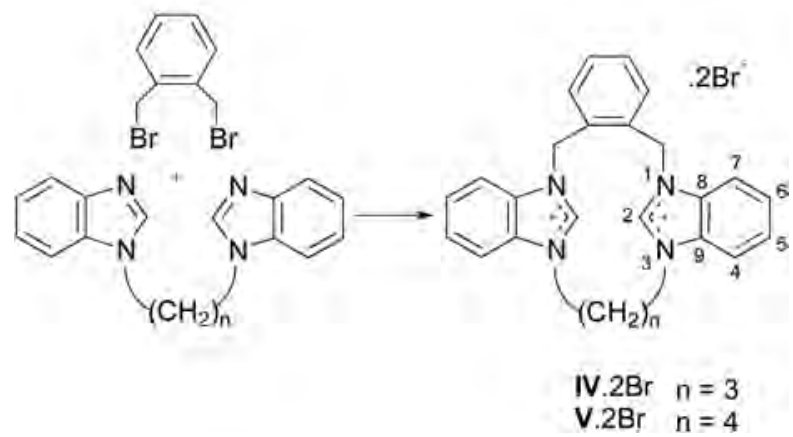

Scheme 1 cyclophane salts $\mathbf{I I I} \cdot 2 \mathrm{Br}$ and $\mathbf{V} \cdot 2 \mathrm{Br}$ crystallised with no additional molecules. Structures of the cyclophane cations and associated bromide ions are shown in Fig. 1 and selected bond lengths and angles are summarized in Table 1, and unit cell contents are provided in the ESI (Fig. S1-S3†). The $\mathrm{C}_{2^{-}}$and $\mathrm{C}_{3^{-}}$ linked cyclophane salts crystallised with molecules of water and/or solvent. Amongst the imidazolium-based cations, structures are seen where the imidazolium units are oriented in the same direction with respect to each other (i.e., mutually syn, with the $\mathrm{H} 2$ hydrogens oriented away from the $o$-xylyl group; $\mathbf{I I}^{2+}$ ), and in opposite directions (i.e., mutually anti; $\mathbf{I}^{2+}, \mathbf{I I I}^{2+}$ ). Both of the benzimidazolium-based cations $\mathbf{I V}^{2+}$ and $\mathbf{V}^{2+}$ adopt conformations in which the benzimidazolium units are mutually syn, with their $\mathrm{H} 2$ hydrogens directed beneath the $o$-xylyl moiety, presumably to avoid unfavourable steric interactions between the benzimidazolium $\mathrm{C}_{6}$ ring and the $o$-xylyl moiety. ${ }^{3,4}$ Interestingly, in all of the cations, the $\mathrm{C}_{2}, \mathrm{C}_{3}$, and $\mathrm{C}_{4}$ linkers exist in staggered conformations. It may be that a preference for this type of conformation, avoiding unfavourable eclipsing interactions, is important in determining the relative orientation of the imidazolium groups in the macrocycles $\mathbf{I}^{2+}$, $\mathbf{I I}^{2+}$ and $\mathbf{I I I}^{2+}$, in the absence of the type of steric interactions that favour the particular syn arrangement seen for the benzimidazolium groups in $\mathbf{I V}^{2+}$ and $\mathbf{V}^{2+}$.

In all cases, the close proximity of bromide counter ions to the $\mathrm{H} 2$ hydrogens of the azolium units is indicative of hydrogen bonding. For the $\mathrm{C}_{2^{-}}$and $\mathrm{C}_{4}$-linked cyclophanes $\mathbf{I}^{2+}, \mathbf{I I I}^{2+}$ and $\mathbf{V}^{2+}$, each $\mathrm{H} 2$ hydrogen is associated with a different bromide ion $(\operatorname{Br}(1)$ or $\operatorname{Br}(2))$. For the $\mathrm{C}_{3}$-linked cyclophane $\mathbf{I I}^{2+}$, in which mutually syn arrangement of the imidazolium groups dictates that the $\mathrm{H} 2$ hydrogens of the two azolium groups are close together $\left(\mathrm{H} \cdots \mathrm{H} \sim 2.69 \AA\right.$; $c f . \mathrm{H} \cdots \mathrm{H} \sim 3.25 \AA$ in $\left.\mathbf{V}^{2+}\right)$, both imidazolium $\mathrm{H} 2$ hydrogens are associated with the same bromide ion $(\mathrm{Br}(2))$. In $\mathbf{I} \cdot 2 \mathrm{Br} \cdot 2 \mathrm{H}_{2} \mathrm{O}$, further hydrogen bonding is observed between $\operatorname{Br}(2)$, water molecules, and the noncation bonded bromide ion, $\operatorname{Br}(1)$ (see ESI, Fig. S2†). The situation in the $\mathrm{C}_{3}$-linked cyclophane $\mathbf{I V}^{2+}$ is more complex. In the crystal structure of $\mathbf{I V} \cdot 2 \mathrm{Br} \cdot \mathrm{EtOH}$ a single bromide counter ion was modelled as disordered over two sites, showing hydrogen bonding to the $\mathrm{H} 2$ hydrogens atoms of the cation (Fig. 1). The structure of the cation is significantly twisted (as is shown clearly in the diagram of the unit cell contents, ESI, Fig. S3†).

NMR spectroscopy. The ${ }^{1} \mathrm{H}$ NMR spectra of the $o$-xylyl linked cyclophanes suggested that in solution the cyclophanes adopted conformations similar to those seen in the solid state. In each case, however, the spectra were exchange-broadened in a manner consistent with processes involving interconversion between two equivalent conformations.

The ${ }^{1} \mathrm{H}$ NMR spectrum of a solution of the $\mathrm{C}_{2}$-linked imidazolium cyclophane salt $\mathbf{I} \cdot 2 \mathrm{Br}$ in $\mathrm{DMSO}^{-\mathrm{d}_{6}}$ at room temperature showed $\mathrm{AA}^{\prime} \mathrm{XX}^{\prime}$ patterns for the protons of the arene group (multiplets at $\delta 7.60-7$ and $\delta$ 7.82-9) and ethylene group (apparent doublets at $\delta 4.22$ and $\delta 4.77$ ), a pair of doublets for the benzylic protons ( $\delta 5.62$ and $\delta 5.72)$ and apparent triplets for the imidazolium $\mathrm{H} 4 / \mathrm{H} 5(\delta 7.43$ and $\delta 7.95)$ and $\mathrm{H} 2(\delta 7.98)$ protons. The signal due to the imidazolium $\mathrm{H} 2$ protons is sur- 

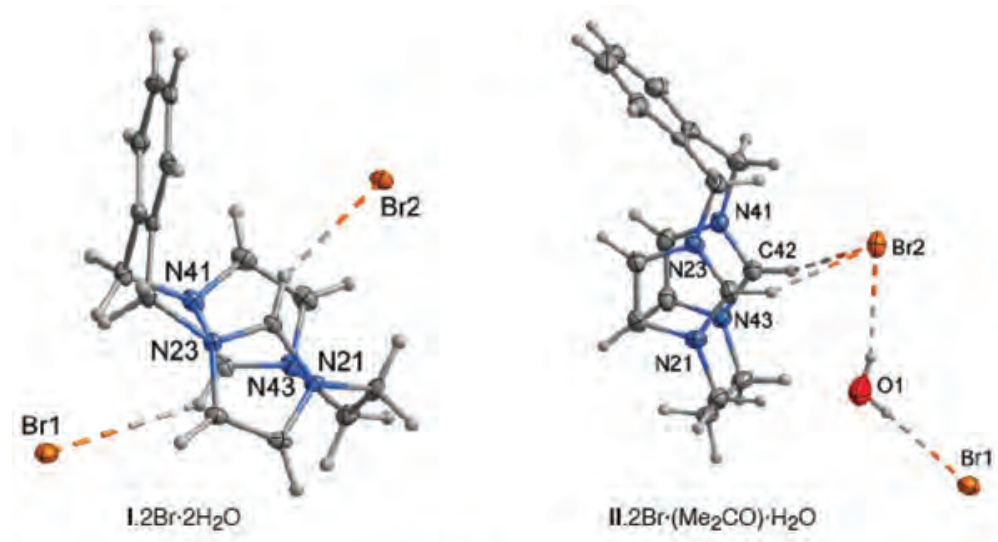

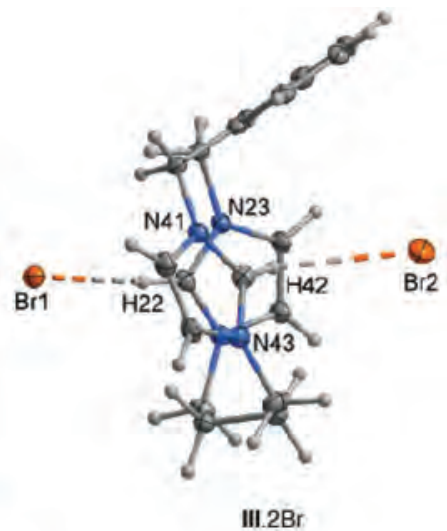

1

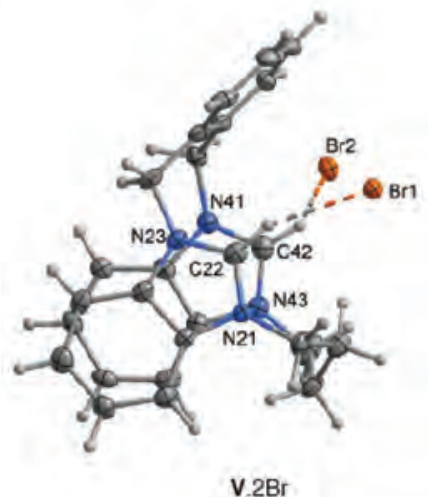

15

IV. $2 \mathrm{Br} \cdot \mathrm{EtOH}$

V. $2 \mathrm{Br}$

Fig. 1 Cations and associated bromide counter ions in the crystal structures of the azolium cyclophane compounds $1 \cdot 2 \mathrm{Br} \cdot 2 \mathrm{H} \mathrm{H}_{2} \mathrm{O}$, $\mathrm{II} \cdot 2 \mathrm{Br}$. $\left(\mathrm{Me}_{2} \mathrm{CO}\right) \cdot \mathrm{H}_{2} \mathrm{O}, \mathrm{III} \cdot 2 \mathrm{Br}, \mathrm{IV} \cdot 2 \mathrm{Br} \cdot(\mathrm{EtOH})$, and $\mathrm{V} \cdot 2 \mathrm{Br}$, highlighting hydrogen bonding between the $\mathrm{C} 2$ hydrogens of the azolium units and the bromide ions. In the cation $\mathrm{V}^{2+}$, the two $\mathrm{C}^{\prime}$ atoms in the $\mathrm{C}_{4}$ chain are disordered over two sites.

Table 1 Selected bond lengths and hydrogen bonding contacts for the asymmetrical azolium cyclophanes

\begin{tabular}{|c|c|c|c|c|c|}
\hline $\mathrm{N} 1_{21 / 41}-\mathrm{C} 2_{22 / 42}(\AA)$ & $1.346(3), 1.328(3)$ & $1.330(4), 1.327(4)$ & $1.332(3), 1.329(3)$ & $1.348(12), 1.335(9)$ & $1.349(6), 1.331(6)$ \\
\hline $\mathrm{H} 2_{22}-\mathrm{Br}_{1 / 2}(\AA)$ & $2.60,3.21$ & $2.69,2.81$ & $2.52,2.91$ & $2.70,2.55$ & $2.67,2.81$ \\
\hline $\mathrm{H} 2_{42}-\mathrm{Br}_{1 / 2}(\AA)$ & & & & $2.74,2.80$ & \\
\hline
\end{tabular}

prisingly upfield compared to the range of $\delta$ 8.5-9.5 typically seen for other imidazolium cyclophanes containing an $o$-xylyl linking group. ${ }^{3,4}$ It may be that the $\mathrm{H} 2$ proton of each imidazolium group is magnetically shielded by the effects of the ring current from the other imidazolium group, and such shielding would seem likely if the conformation of $\mathbf{I}^{2+}$ seen in the solid state (Fig. 1) persists in solution.

Indeed, the number of ${ }^{1} \mathrm{H}$ NMR signals and their splitting patterns are consistent with the cyclophane $\mathbf{I}^{2+}$ existing in two equivalent conformations in which the imidazolium groups are mutually anti (as seen in the X-ray study) which interconvert by "flipping" of the xylyl group (Fig. 2a). An exchange process involving rotation of each of the imidazolium units about its $\mathrm{N} \cdots \mathrm{N}$ axis, but without flipping of the xylyl group, would also account for the appearance of the ${ }^{1} \mathrm{H}$ NMR spec- trum. However, such an exchange process would seem unlikely to occur, given the small size of the cyclophane ring and the steric hindrance that would occur as the $\mathrm{H} 2$ or H4/H5 hydrogens "sweep" through the interior of the ring. The exchange process cannot involve both the flipping of the xylyl group and the rotation of the imidazolium groups, because that combination of processes would result in the signals due to the benzylic protons and the signals due to the ethylene protons both collapsing to singlets. The ${ }^{1} \mathrm{H}$ NMR spectrum of a solution of $\mathbf{I} \cdot 2 \mathrm{Br}$ in $\mathrm{CD}_{3} \mathrm{OD}$ at room temperature (Fig. $2 \mathrm{~b}$ ) was similar to the one obtained in DMSO- $\mathrm{d}_{6}$, except that the signal due to imidazolium $\mathrm{H} 2$ protons was absent (due to $\mathrm{H} / \mathrm{D}$ exchange) and the benzylic protons appeared as an apparent singlet. As the temperature was lowered, the exchange process was slowed and signal broadening was evident (Fig. 2c and d). 
a)
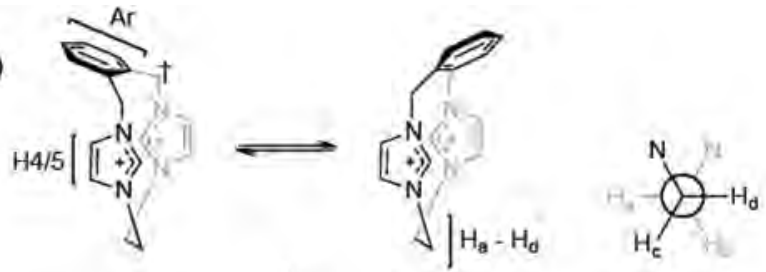

10

15

20

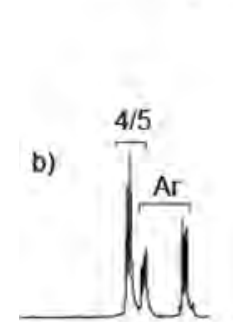

c)

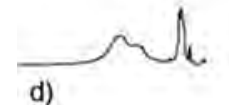

d)

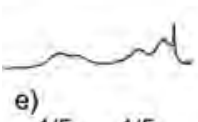

e)

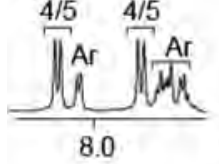

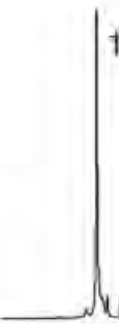

t

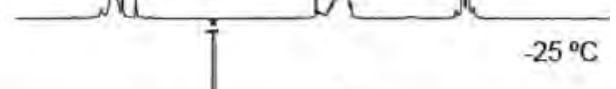

$25^{\circ} \mathrm{C}$
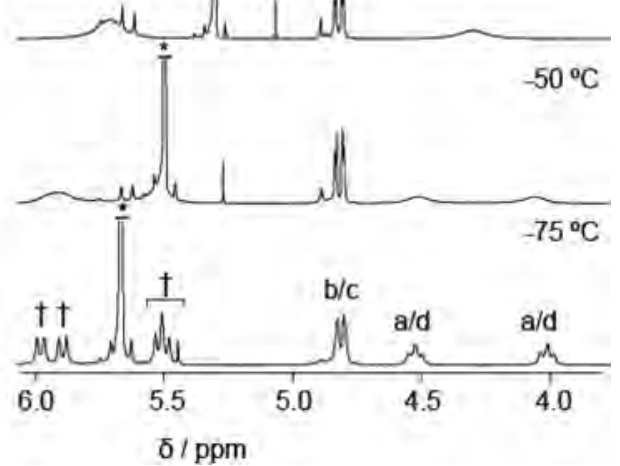

Fig. 2 Variable temperature ${ }^{1} \mathrm{H}$ NMR study of I.2Br. (a) Interconversion of equivalent conformations of $\mathrm{I}^{2+}$ by "flipping" of the xylyl group. (b)-(e) ${ }^{1} \mathrm{H}$ NMR spectra $\left(500.1 \mathrm{MHz}, \mathrm{CD}_{3} \mathrm{OD}\right)$ of $\mathrm{I} \cdot 2 \mathrm{Br}$ at $25,-25,-50$, and $-75^{\circ} \mathrm{C}$ respectively. In (b), the signal due to $H_{b} / H_{c}$ is partly obscured by the signal for adventitious water (labelled with an asterisk, *).

At $-78{ }^{\circ} \mathrm{C}$ (Fig. 2e), the spectrum showed a larger number of signals (e.g., four doublets corresponding to four non-equivalent benzylic protons), consistent with the cyclophane $\mathbf{I}^{2+}$ being rigid on the NMR timescale, lacking any plane or axis of symmetry, in the conformation seen in the X-ray study. There was no evidence for the existence of a conformation of $\mathbf{I}^{2+}$ in which the imidazolium groups were mutually syn.

Fig. 3 shows the results of a variable-temperature ${ }^{1} \mathrm{H}$ NMR study of the imidazolium $\mathrm{C}_{3}$-linked cyclophane $\mathbf{I I} \cdot 2 \mathrm{Br}$ in $\mathrm{CD}_{3} \mathrm{OD}$ solution. At room temperature (Fig. 3c), the ${ }^{1} \mathrm{H}$ NMR signals for the cation $\mathbf{~ I I}^{2+}$ were broad, indicating that the cyclophane is conformationally labile on the NMR timescale. At higher temperature (Fig. 3b), various signals coalesce and sharpen (but most remain somewhat broadened), the number of signals being consistent with the cyclophane having an effective plane of symmetry that bisects the xylyl group and the $\mathrm{C}_{3}$ chain. The broad signals seen at room temperature separate into signals due to two distinct conformations (A) and (B) (Fig. 3a) when the temperature is lowered (Fig. 3d) and the two conformations are eventually "frozen out" at $-25{ }^{\circ} \mathrm{C}$ (Fig. 3e). a)

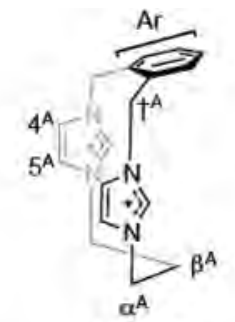

(A) (major)
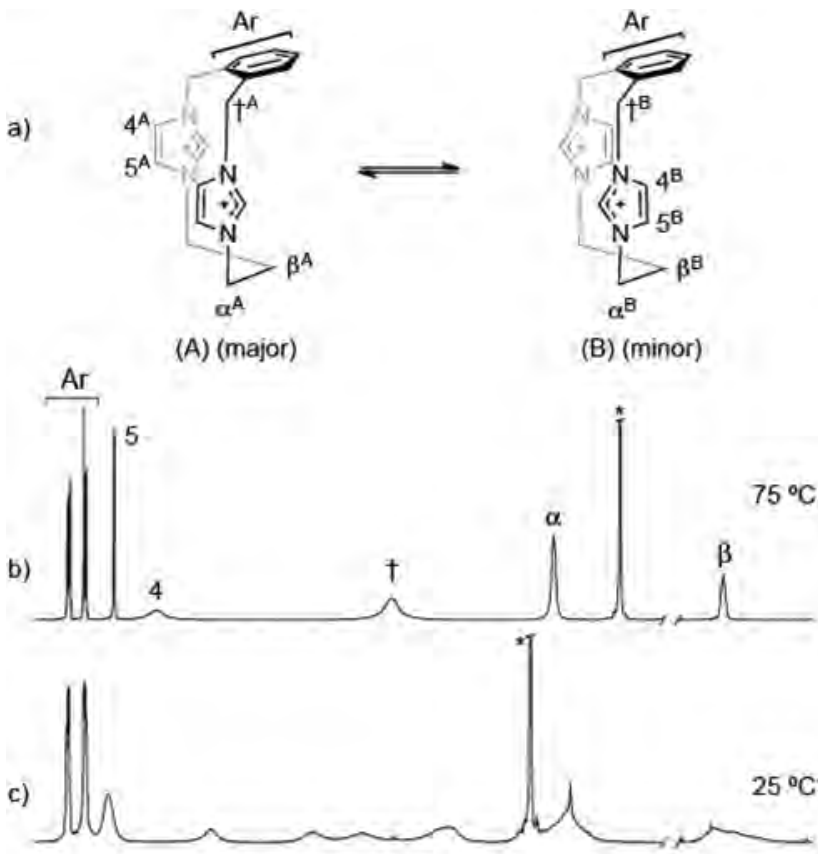

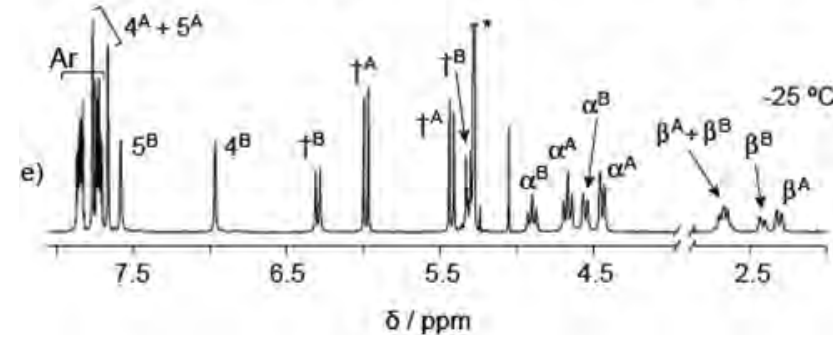

Fig. 3 Variable temperature ${ }^{1} \mathrm{H}$ NMR study of II.2Br. (a) Interconversion of the (A) and (B) conformations of $\mathrm{III}^{2+}$. The conformation of the $\mathrm{C}_{3}$ chain could not be determined by ${ }^{1} \mathrm{H}$ NMR and for illustrative convenience is based on that seen in the X-ray study. (b)-(d) ${ }^{1} \mathrm{H}$ NMR spectra (500.1 MHz, CD 3 OD) of $\mathrm{III} \cdot 2 \mathrm{Br}$ at 75,50 , and $25^{\circ} \mathrm{C}$ respectively. The signal due to adventitious water is labelled with an asterisk, *).

The number of signals and coupling patterns for each of the conformations indicate that the imidazolium groups are mutually syn in both. For the major conformation (tentatively assigned as (A), Fig. 3a), the signals of the imidazolium $\mathrm{H} 4$ and $\mathrm{H} 5$ protons have similar downfield chemical shifts $(\delta 7.69$ and 7.78). For the minor conformation (tentatively assigned as (B), Fig. 3a), the chemical shifts of the signals of the imidazolium $\mathrm{H} 4$ and $\mathrm{H} 5$ protons are quite different ( $\delta 6.95$ and 7.58), presumably because the $\mathrm{H} 4$ protons are magnetically shielded by the ring current associated with the xylyl group. ${ }^{3}$ Interestingly, conformation (A) is intuitively the less sterically hindered of the two conformations, having the smaller portion of the imidazolium groups directed beneath the xylyl group, 
but the intuitively more hindered (B) is seen in the solid state (Fig. 1). Perhaps in the solid state, $\mathrm{H} 2 \cdots \mathrm{Br}$ H-bonding tips the balance in favour of conformation (B), while in methanol solution, solvation disrupts the $\mathrm{H} 2 \cdots \mathrm{Br}$ interactions. ${ }^{4}$

Like its imidazolium analogue $\mathbf{I I}^{2+}$, the benzimidazolium cyclophane $\mathbf{I V}^{2+}$ in solution exists in two conformations, but these conformations are rigid on the NMR timescale at room temperature. The ${ }^{1} \mathrm{H}$ NMR spectrum of a DMSO- $\mathrm{d}_{6}$ solution of IV.2Br ([D $\left.\left.\mathrm{D}_{6}\right] \mathrm{DMSO}\right)$ at $25{ }^{\circ} \mathrm{C}$ (Fig. $4 \mathrm{~d}$ and e) shows two sets of sharp multiplets, the number of signals, splitting patterns, and chemical shifts allowing the major and minor confor-

a)

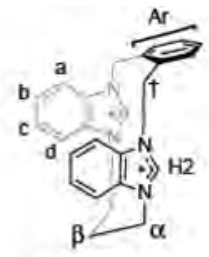

(C) (major)
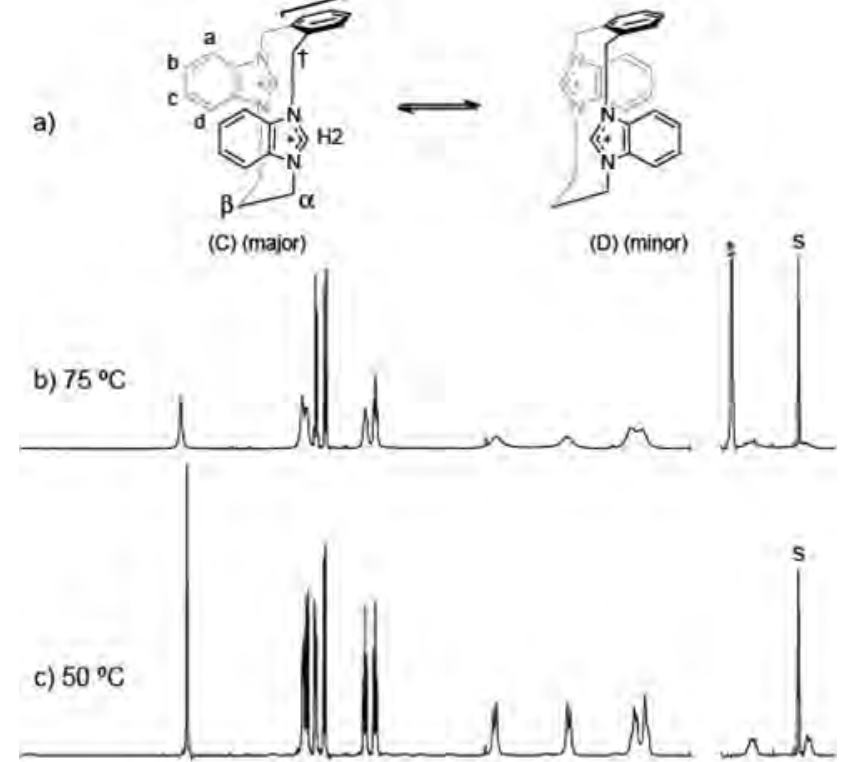

35

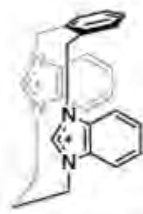

(D) (minor)

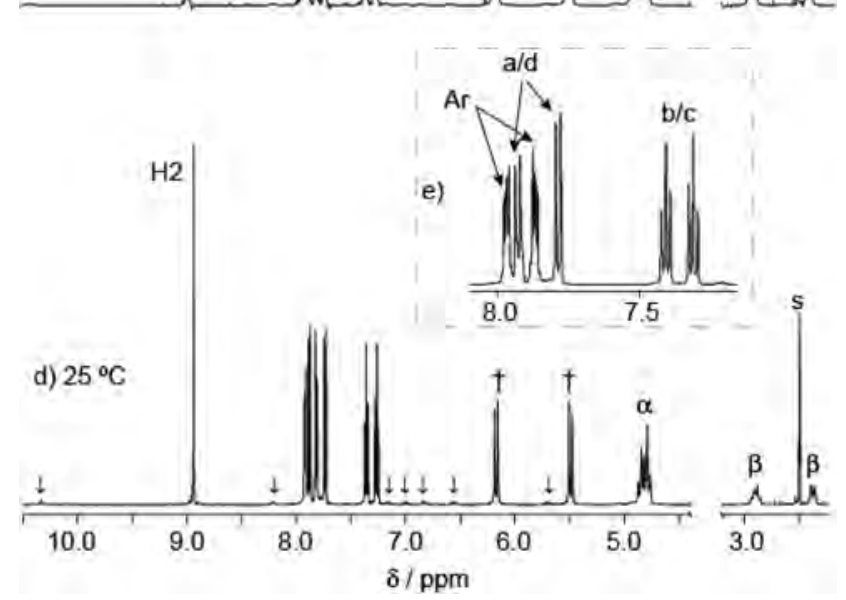

Fig. 4 Variable temperature ${ }^{1} \mathrm{H}$ NMR study of IV.2Br. (a) Interconversion of the (A) and (B) conformations of $\mathrm{II}^{2+}$. The conformation of the $\mathrm{C}_{3}$ chain could not be determined by ${ }^{1} \mathrm{H}$ NMR and for illustrative convenience is based on that seen in the X-ray study. (b)-(d) ${ }^{1} \mathrm{H}$ NMR spectra $\left(500.1 \mathrm{MHz}, \mathrm{DMSO}-\mathrm{d}_{6}\right)$ of IV.2Br at 75,50 , and $25^{\circ} \mathrm{C}$ respectively. (e) Expansion of the aromatic region of the spectrum in (d). In (d) and (e), labels identify signals due to the major conformation (A) and arrows highlight signals due to the minor conformation (B). The signal due to adventitious water is labelled with an asterisk, (*) and the residual solvent signal is labelled "s". mations to be assigned as (C) and (D) respectively (Fig. 4a). In this case, conformation (C) is strongly favoured over conformation (D), the latter presumably being destabilised by steric interactions between the xylyl group and the benzimidazolium groups. Due to magnetic shielding of the benzimidazolium $\mathrm{H} 2$ proton in conformation (C) by the ring current associated with the xylyl group, ${ }^{3}$ the signal of this proton $(\delta$ 8.94) appears significantly upfield of the signal of the $\mathrm{H} 2$ proton for conformation (D) ( $\delta$ 10.34). At elevated temperatures (Fig. $4 \mathrm{~b}$ and c), ${ }^{1} \mathrm{H}$ NMR signals due to the minor conformation (D) broaden and merge into the baseline and signals due to the major conformation (C) also significantly broaden, suggesting that the two conformations interconvert on the NMR timescale at elevated temperatures.

The ${ }^{1} \mathrm{H}$ NMR spectra of solutions of $\mathbf{I I I} \cdot 2 \mathrm{Br}$ and $\mathbf{V} \cdot 2 \mathrm{Br}$ at room temperature showed signals consistent with the cations $\mathrm{III}^{2+}$ and $\mathbf{V}^{2+}$ existing as rapidly interconverting conformations (see ESI, Fig. S4 and S5†). For example, in both cases, the benzylic protons of the xylyl group appeared as sharp singlets, not the AX doublet patterns characteristic of benzylic protons in conformationally rigid azolium cyclophanes. Evidently, the larger macrocycle size provided by the presence of the $\mathrm{C}_{4}$ linker in $\mathbf{I I I}^{2+}$ and $\mathbf{V}^{2+}$ facilitates interconversion of conformations, presumably via processes involving rotation of the azolium groups about their $\mathrm{N}-\mathrm{N}$ axes, allowing the $\mathrm{H} 2$ end of the azolium group to swing through the macrocyclic ring. The ${ }^{1} \mathrm{H}$ NMR spectra for $\mathbf{I I I}^{2+}$ and $\mathbf{V}^{2+}$ broadened at low temperatures, but even at $-60{ }^{\circ} \mathrm{C}$ (for $\mathbf{I I I}^{2+}$ ) and $-75{ }^{\circ} \mathrm{C}$ (for $\mathbf{V}^{2+}$ ) the exchange processes were not slowed sufficiently for signals due to individual conformations to be observed.

\section{Au(I)-NHC complexes}

Synthesis and NMR spectroscopy. In a similar fashion to that used for the preparation of $1 \cdot 2 \mathrm{Br},{ }^{27}$ heating a $1: 1$ mixture of an azolium cyclophane salt (III·2Br, IV·2Br or $\mathbf{V} \cdot 2 \mathrm{Br}$ ) and an $\mathrm{Au}(\mathrm{I})$ source $\left(\left(\mathrm{CH}_{3}\right)_{2} \mathrm{SAuBr}\right)$ in the presence of a mild base (sodium acetate) afforded $\mathrm{Au}(\mathrm{I})-\mathrm{NHC}$ complexes $2^{2+}, 3^{2+}$, and $4^{2+}$ respectively (Scheme 2) as their bromide salts. The complexes are of general form $\mathrm{Au}_{2} \mathrm{~L}_{2}{ }^{2+}$, where $\mathrm{L}$ is a cyclophane bis (NHC) ligand. In each case, two stereoisomers of each cation were generated as a consequence of the asymmetry in the ligands, a cis isomer where the cyclophane supporting ligands are arranged with their $o$-xylyl groups on the same side of the plane defined by the carbene $\mathrm{C}$ atoms, and a trans isomer where the $o$-xylyl groups are on the opposite sides of this plane. Numerous attempts to synthesize $\mathrm{Au}(\mathrm{I})$ complexes from the $\mathrm{C}_{2}$-linked cyclophane $\mathbf{I} \cdot 2 \mathrm{Br}$ afforded only intractable solids.

The ${ }^{1} \mathrm{H}$ NMR spectra were as expected for complexes of form $\mathrm{Au}_{2} \mathrm{~L}_{2}{ }^{2+}$ that are rigid in solution. ${ }^{13}$ For example, the benzylic protons of the xylyl groups in each complex appeared as a pair of doublets, a pattern characteristic for cyclophane bis(NHC) complexes in which each benzylic carbon carries protons in non-equivalent endo and exo environments. ${ }^{11,13}$ Due to the symmetry properties of each complex (cis isomers, one two-fold proper rotation axis and two vertical reflection planes, point group $C_{2 v}$; trans isomers, one two-fold proper 

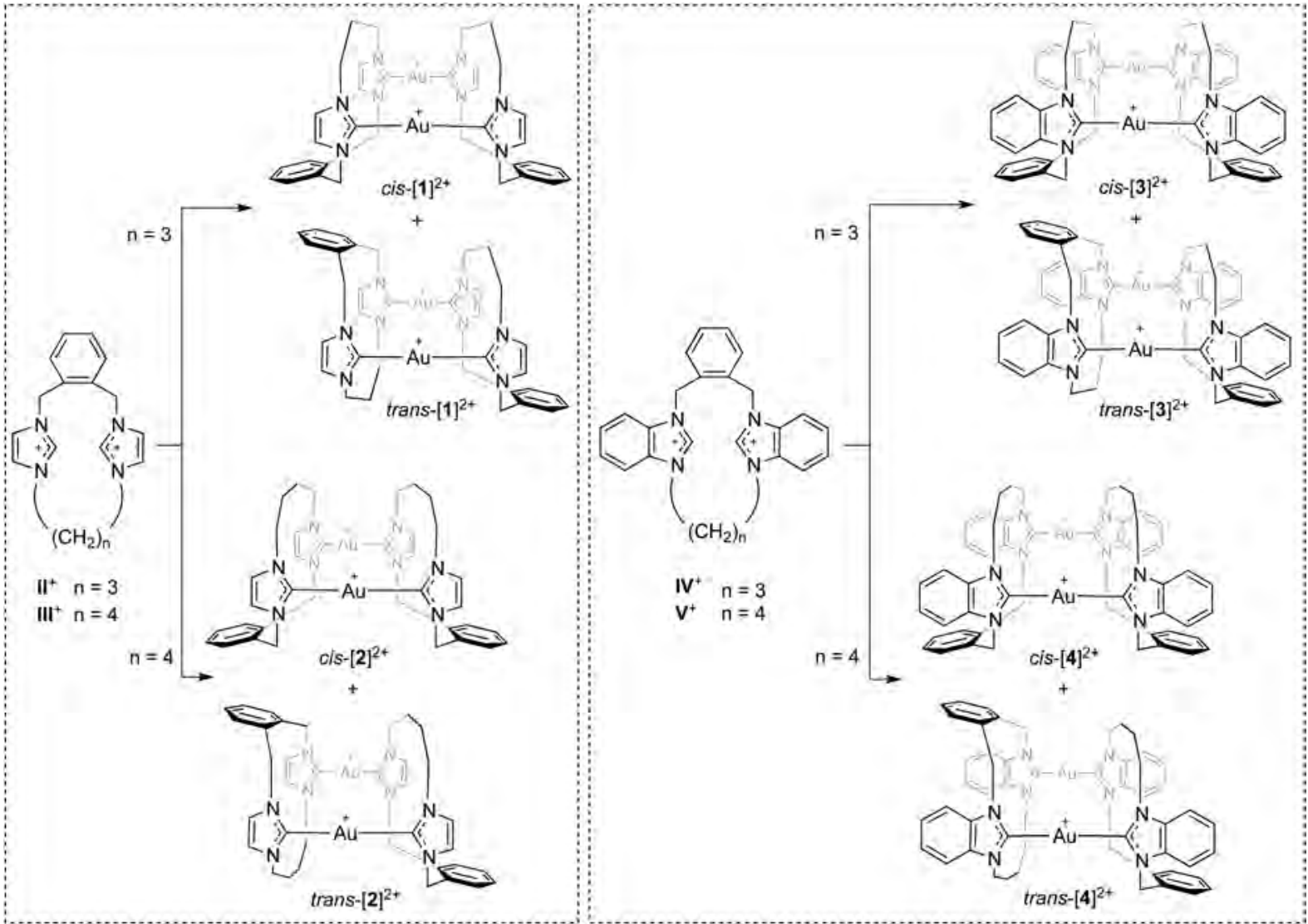

rotation axis and one horizontal reflection plane, point group $C_{2 \mathrm{~h}}$ ) NMR spectra of cis and trans isomers each showed the same number of signals, which had similar chemical shifts and splitting patterns, so the stereochemistry of each complex could not be readily assigned by NMR spectroscopy.

X-ray crystallography. X-Ray diffraction studies were undertaken for crystals of cis-2. $\mathrm{BrCl} \cdot 3 \mathrm{H}_{2} \mathrm{O}$, trans$2 \cdot \mathrm{Br}_{0.75} \mathrm{Cl}_{1.25} \cdot 4 \mathrm{MeOH} \cdot 2 \mathrm{H}_{2} \mathrm{O}, \quad$ cis-3 $2 \mathrm{Br} \cdot 2 \mathrm{MeOH} \cdot 3 \mathrm{H}_{2} \mathrm{O}, \quad$ cis$4 \cdot 2 \mathrm{Br} \cdot 2 \mathrm{MeOH}$ and trans $-4 \cdot 2 \mathrm{Br} \cdot 3 \mathrm{MeOH}$, containing the cations cis $-2^{2+}$, trans $-2^{2+}$, cis $-3^{2+}$, cis $-\mathbf{4}^{2+}$ and trans $-4^{2+}$ respectively. The structures of the cations are shown in Fig. 5 and 6, while selected bond lengths and angles obtained are given in Table 2, along with those of the cations $c i s-\mathbf{1}^{2+}, \operatorname{trans}-\mathbf{1}^{2+}$, and $5^{2+}$ reported previously. ${ }^{13,27}$

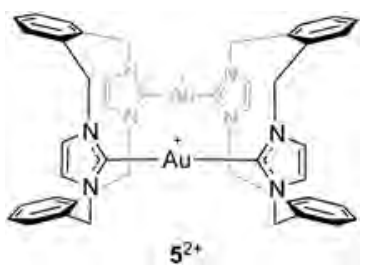

All of the new compounds contained a dinuclear cation of form $\mathrm{Au}_{2} \mathrm{~L}_{2}{ }^{2+}$ ( $\mathrm{L}=$ cyclophane bis(NHC) ligand), two halide counterions, and solvent molecules. In the cation, the $o$-xylyl groups are splayed away from the $\mathrm{Au}$ atoms, as has been found previously in all other $\mathrm{Au}_{2} \mathrm{~L}_{2}{ }^{2+13} \mathrm{Ag}_{2} \mathrm{~L}_{2}{ }^{2+}, 39$ and $\mathrm{Hg}_{2} \mathrm{~L}_{2}{ }^{2+}$ complexes $^{40}$ in which $o$-xylyl link the NHC moieties. While the $\mathrm{Au}-\mathrm{C} 2$ distances are unexceptional, $\mathrm{Au} \cdots \mathrm{Au}$ distances are short in all the cations, consistent with there being aurophilic interactions between the $\mathrm{Au}$ centres. The $\mathrm{Au} \cdots \mathrm{Au}$ distance appears to be largely determined by the nature of the groups linking the NHC units, being shorter in the complexes with one $o$-xylyl and one $\mathrm{C}_{3}$-linker (cis- and trans- $\mathbf{1}^{2+}$ and $c i s-3^{2+}$, average $\sim 2.940 \AA$ ) and longer in the complexes with one $o$-xylyl and one $\mathrm{C}_{4}$ linker (cis- and trans- $\mathbf{2}^{2+}$ and cis- and trans $-\mathbf{4}^{2+}$, average $\sim 3.198 \AA$ ). In complex $\mathbf{5}^{2+}$, having two $o$-xylyl linkers, the $\mathrm{Au} \cdot \cdots \mathrm{Au}$ distance falls in between (3.0485 $⿱$ $)$, presumably because the larger $\mathrm{C}-\mathrm{C}-\mathrm{C}$ bond angles and shorter arene $\mathrm{C}-\mathrm{C}$ bond in the $\mathrm{C}_{4}$ linking portion of the $o$-xylyl unit result in the $o$-xylyl unit being effectively "shorter" than the simple tetramethylene $\mathrm{C}_{4}$ group. Interestingly, for the cations $2^{2+}$ and $4^{2+}$, both of which contain a $\mathrm{C}_{4}$ linker, the $\mathrm{Au} \cdots \mathrm{Au}$ distance is significantly longer in the cis isomer than in the trans isomer. In all the cations, the planes of the NHC groups in each cyclophane slightly tilt towards each other at their carbene ends, as indicated by $\mathrm{C} 2-\mathrm{Au}-\mathrm{C} 2$ angles in the range $173.0-179.4^{\circ}$.

For cis-2. $\mathrm{BrCl} \cdot 3 \mathrm{H}_{2} \mathrm{O}$, the anionic sites were modelled as being partially occupied by chloride and bromide ions (site 1), 

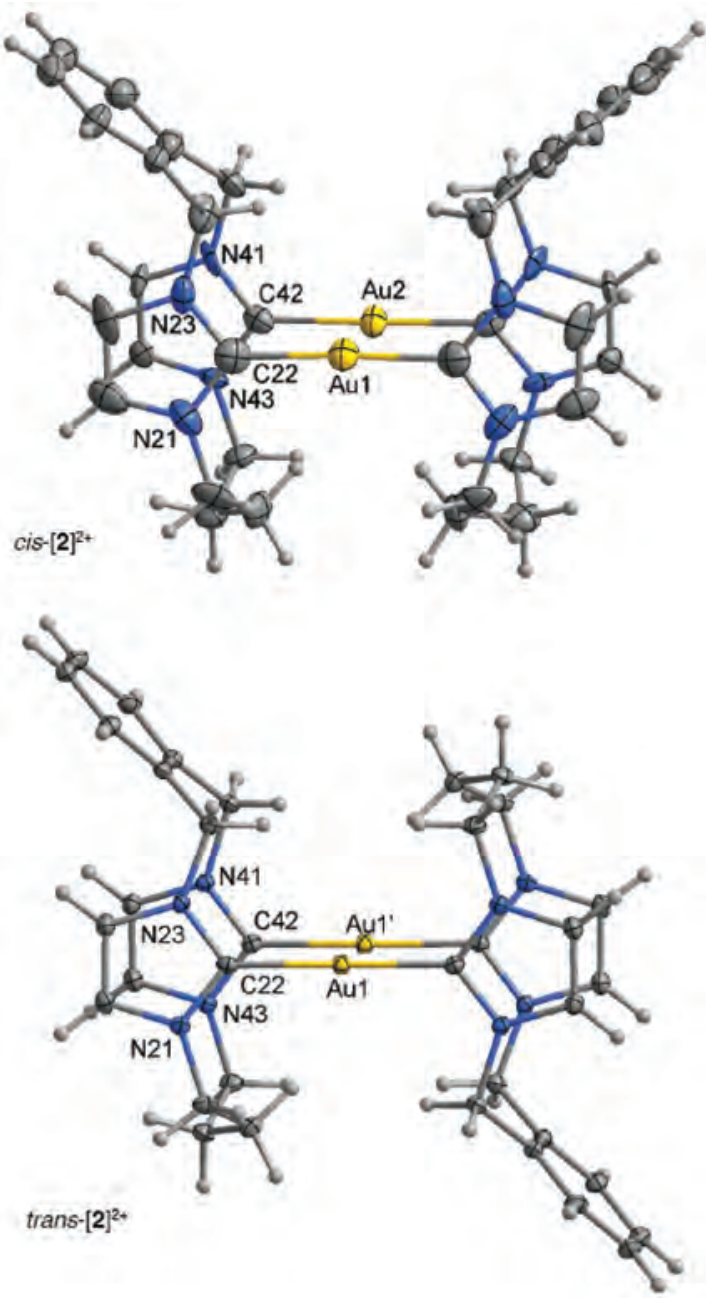

Fig. 5 Structures of cations cis-[2] $]^{2+}$ and trans- $[2]^{2+}$, containing imidazolyl-derived $\mathrm{C}_{4}$-linked cyclophane ligands. Unit cell contents are shown in the ESI, Fig. S6. $\dagger$

bromide ions and water (site 2), or chloride ions and water (site 3), with occupancies set at 0.5 after trial refinement. The cation cis- $2^{2+}$ is situated on a crystallographic mirror plane perpendicular to the crystallographic $a$ axis, and the unit cell projection (ESI, Fig. S6a†) shows that the cations lie parallel to the ac plane, alternating with planes containing counter ions and water molecules. For trans-2. $\mathrm{Br}_{0.75} \mathrm{Cl}_{1.25} \cdot 4 \mathrm{MeOH} \cdot 2 \mathrm{H}_{2} \mathrm{O}$, the anions were refined as part bromide and part chloride, with the occupancies refined to $0.624(2)$ and 1-0.624(2) for chloride and bromide, respectively. The cation trans $-2^{2+}$ lies on a crystallographic inversion centre. The halide counter ions in the lattice, as well as the water and methanol molecules, form a hydrogen bonded cluster around the cell origins as shown in the cell projected along the $a$ axis (ESI, Fig. S6b $\dagger$ ).

For cis-3.2Br.2MeOH$\cdot \mathrm{H}_{2} \mathrm{O}$, containing benzimidazolyl $\mathrm{C}_{3}$ linked cyclophane ligands, one methanol molecule crystallised inside the 'cup' formed by the $o$-xylyl groups (Fig. 6a). The unit cell projection along the $b$ axis (ESI, Fig. S7a $\dagger$ ) shows that the cations lie in sheets, parallel to the $b c$ plane, and alternate

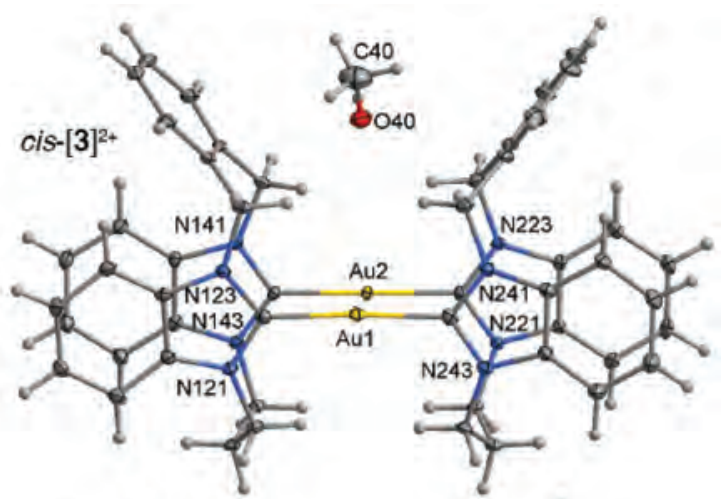

1

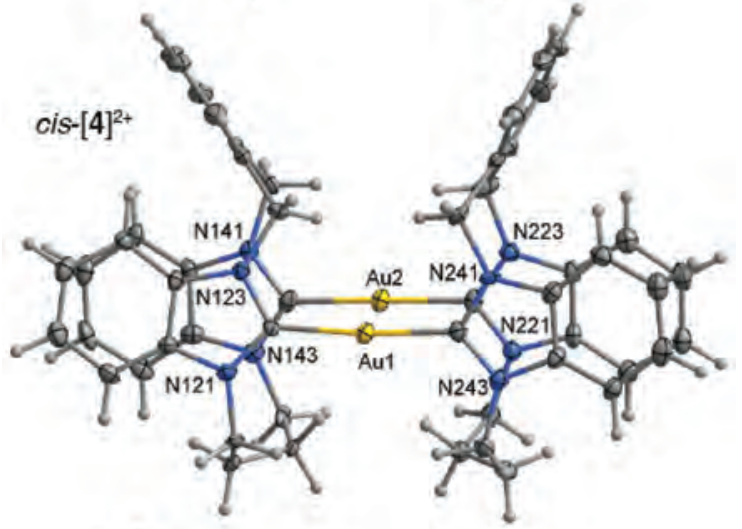

15

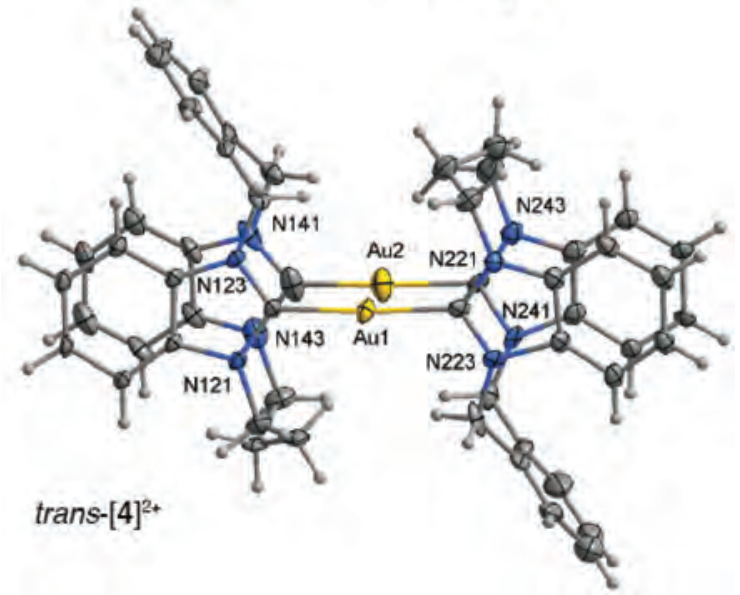

30

Fig. 6 Structures of cations cis-[3] ${ }^{2+}$, cis- $[4]^{2+}$, and trans- $[4]^{2+}$, containing benzimidazolyl-derived cyclophane ligands. For cis-[3] ${ }^{2+}\left(\mathrm{C}_{3}\right.$-linked), a molecule of methanol is shown co-crystallised inside the 'cups' formed by the two o-xylyl groups. For both cis- $[4]^{2+}$ and trans- $[4]^{2+}\left(\mathrm{C}_{4}{ }^{-}\right.$ linked), only one component of the disordered atoms has been included. Unit cell contents are shown in the ESI, Fig. S7.†

with sheets containing bromide ions, methanol, and water 50 molecules.

The atoms of the $\mathrm{C}_{4}$ linker in the cation $c i s-\mathbf{4}^{2+}$ were disordered over two sites, with occupancies refined to $0.708(3)$ and its complement. The solvent was modelled as two methanol molecules (not shown), both disordered over two sets of sites, with occupancies constrained, after trial refinement, to be the same as the disordered $\mathrm{C}_{4}$ moiety. The unit cell diagram for $c i s-4 \cdot 2 \mathrm{Br} \cdot 3 \mathrm{MeOH}$, projected along the $a$ axis (ESI, 
Table 2 Selected bond lengths and angles for the dinuclear Au(I)-NHC complexes

\begin{tabular}{|c|c|c|c|c|}
\hline Cation & Space group & $\mathrm{Au}-\mathrm{C} 2_{22 / 42}(\AA)$ & $\mathrm{C} 2-\mathrm{Au}-\mathrm{C} 2\left(^{\circ}\right)$ & $\operatorname{Au}(\mathrm{I}) \cdots \operatorname{Au}(\mathrm{I})(\AA)$ \\
\hline cis $-\mathbf{1}^{2+a}$ & $C 2 / c$ & $2.035(6), 2.033(6)$ & $177.4(3)$ & $2.9290(4)$ \\
\hline $\operatorname{trans}-\mathbf{1}^{2+a}$ & $C 2 / c$ & $2.036(6), 2.029(6)$ & $175.5(3)$ & $2.9582(4)$ \\
\hline cis $-2^{2+b}$ & $P m c 2_{1}$ & $1.963(9), 2.051(7)$ & $177.0(5), 176.8(4)$ & $3.2880(6)$ \\
\hline $\operatorname{trans}-2^{2+c}$ & $P \overline{1}$ & $2.0239(17), 2.0216(17)$ & $176.07(7)$ & $3.1402(4)$ \\
\hline cis $-3^{2+d}$ & $P \overline{1}$ & $2.0276(19), 2.033(2), 2.0266(18), 2.0269(19)$ & $174.84(8), 179.44(7)$ & $2.93289(12)$ \\
\hline$c i s-4^{2+e}$ & $C 222_{1}$ & $2.028(3), 2.034(4), 2.029(4), 2.030(4)$ & $174.19(15), 177.66(15)$ & $3.2318(2)$ \\
\hline $\operatorname{trans}-\mathbf{4}^{2+f}$ & $P 2_{1} / n$ & $2.021(16), 2.035(17), 1.97(2), 2.077(18)$ & $176.5(8), 176.3(7)$ & $3.1301(11)$ \\
\hline $5^{2+g}$ & $\operatorname{Pca2}_{1}$ & $1.997(5), 2.066(6) 1.979(6), 2.061(6)$ & $173.0(2) 176.9(2)$ & $3.0485(3)$ \\
\hline
\end{tabular}

${ }^{a}$ Crystal structure for (cis-1,trans-1-4Br-2' $\left.\mathrm{H}_{2} \mathrm{O}^{\prime}\right)_{0.5}=\mathrm{C}_{34} \mathrm{H}_{38} \mathrm{Au}_{2} \mathrm{Br}_{2} \mathrm{~N}_{8} \mathrm{O} .{ }^{27}{ }^{b}$ Crystal structure for cis-2 $\cdot \mathrm{BrCl} \cdot 3 \mathrm{H}_{2} \mathrm{O}$. ${ }^{c} \mathrm{Crystal}$ structure for trans-

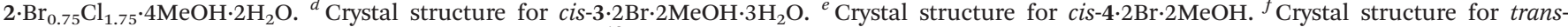
4.2Br-3MeOH. ${ }^{g}$ Crystal structure for trans-5.2Br-2MeCN. ${ }^{13}$

Fig. S7b $\dagger$ ) shows a weak interaction between $\operatorname{Br}(1)$ and $\mathrm{Au}(2)$ atoms of adjacent cations, with the shortest $\mathrm{Br}(1)-\mathrm{Au}(2)$ distance found to be 3.9559(2) $\AA$. The crystal structure of trans$4 \cdot 2 \mathrm{Br} \cdot 3 \mathrm{MeOH}$ contained bromide counter ions that are disordered over five sites, with the sum of their occupancies constrained to be 2. The three solvent molecules (methanol), in which the hydroxyl hydrogens were refined as part of riding models, were restrained for possible hydrogen bonding to $\operatorname{Br}(3)$ and $\operatorname{Br}(4)$. Furthermore, the central two $\mathrm{C}$ atoms of the $\mathrm{C}_{4}$ linker of trans-4 ${ }^{2+}$ were disordered over two sets of sites, with occupancies set to 0.5 after a trial refinement. The unit cell contents for trans-4.2Br-3MeOH is shown in Fig. S7c (ESI†).

Luminescence characteristics. The solution luminescence behaviour of cis-1.2Br and trans-1.2Br has been reported previously. ${ }^{27}$ We found that aqueous solutions of cis-3.2Br and trans-3.2Br also exhibited intense luminescence, most likely due to the close proximity of the $\mathrm{Au}(\mathrm{I})$ centres ions at the core of the complex ( $\mathrm{Au} \cdots \mathrm{Au} \sim 2.9 \AA$ in the crystal structure). The luminescence excitation and emission spectra for aqueous solutions of the cis-3.2Br are shown in Fig. 7; those for trans$3 \cdot 2 \mathrm{Br}$ were essentially identical. The electronic absorption spectrum shows two main bands, centred at 288 and $345 \mathrm{~nm}$. The luminescence emission spectrum $\left(\lambda_{\mathrm{ex}}=288 \mathrm{~nm}\right)$ shows a strong band at $431 \mathrm{~nm}$ and a weaker band at $555 \mathrm{~nm}$. The excitation spectrum $\left(\lambda_{\mathrm{em}}=431 \mathrm{~nm}\right)$ is very similar to the electronic absorption spectrum, with maxima at 288 and $345 \mathrm{~nm}$. The emission quantum yields $(\Phi)$ are $0.63\left(\lambda_{\mathrm{ex}}=288 \mathrm{~nm}\right)$ and 0.84 $\left(\lambda_{\mathrm{ex}}=345 \mathrm{~nm}\right)$ when relative to quinine sulfate. ${ }^{41,42}$ Complexes $2.2(\mathrm{Br} / \mathrm{Cl})$ and $4 \cdot 2 \mathrm{Br}$, bearing the cyclophane supporting ligands with $\mathrm{C}_{4}$-linked alkyl chains, were found to have significantly longer intramolecular $\mathrm{Au} \cdots \mathrm{Au}$ distances in the solid state $(\sim 3.3 \AA)$. While complexes $2.2(\mathrm{Br} / \mathrm{Cl})$ and $\mathbf{4} \cdot 2 \mathrm{Br}$ displayed luminescence in aqueous solution, luminescence measurements were difficult due to their low solubility. The higher luminescence of solutions containing the $\mathrm{C}_{3}$-linked cyclophane complexes $c i s-1^{2+}$ or $c i s-3^{2+}$ compared to that for solutions containing the $\mathrm{C}_{4}$-linked cyclophane complexes $c i s-2^{2+}$ or cis-4 ${ }^{2+}$ can be seen qualitatively by illumination of solutions with a TLC lamp (Fig. S8†).

Biological studies of $\mathrm{Au}^{\mathrm{I}}-\mathrm{NHC}$ complexes. All attempts to measure cytotoxicity of bromide salts of cis and trans isomers of $2^{2+}$ and $4^{2+}$ in HeLa cells resulted in large crystals of the
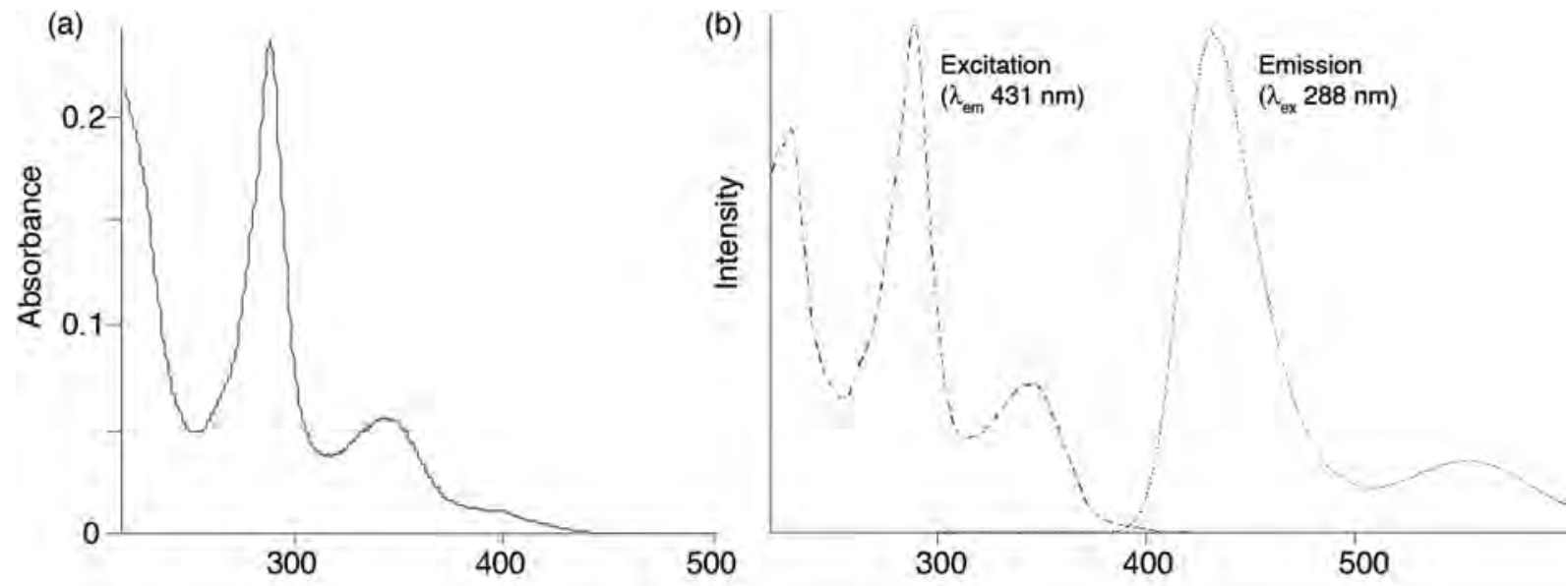

Wavelength $(\mathrm{nm})$

Fig. 7 (a) Electronic absorption and (b) luminescence excitation (dashed line, $\lambda_{\mathrm{em}}=431 \mathrm{~nm}$ ) and emission (dotted line, $\lambda_{\mathrm{ex}}=288 \mathrm{~nm}$ ) spectra for cis-3.2Br $(5 \mu \mathrm{M}$ in water). 
$\mathrm{Au}-\mathrm{NHC}$ complexes appearing in the culture wells. For this reason, representative cell proliferation studies were carried out on HeLa cells using the cis and trans isomers of the $\mathrm{Au}$ complexes $1 \cdot 2 \mathrm{Br}$ and $3 \cdot 2 \mathrm{Br}$ only. The CellTiter $96{ }^{\circledR}$ Aqueous One Solution Reagent assay was used, based on the reduction of a tetrazolium ion ([3-(4,5-dimethylthiazol-2-yl)-5-(3-carboxy-

methoxyphenyl)-2-(4-sulfophenyl)- $2 H$-tetrazolium, MTS) to a coloured formazan product only in healthy and metabolically active cells, and the results are shown in Fig. S9. $\dagger$ The data showed that cis-1.2Br and trans-1.2Br caused a decrease in the number of viable HeLa cells in culture to $\mathrm{ca}$. $60 \%$ at concentrations of $100 \mu \mathrm{M}$ and $75 \mu \mathrm{M}$, respectively, over a period of $24 \mathrm{~h}$. Similarly, cis-3.2Br and trans-3.2Br caused a decrease in the percentage of viable cells to $c a .60 \%$ at $82 \mu \mathrm{M}$ and $75 \mu \mathrm{M}$, respectively. These data show that these Au-NHC complexes have low cytotoxicity $\left(\mathrm{IC}_{50}\right.$ values $\left.>100 \mu \mathrm{M}\right)$ in HeLa cells.

The lipophilicity of the cis isomers of each of $\mathrm{Au}-\mathrm{NHC}$ complexes (Table 3) was assessed using the octanol-water partition coefficient, $\log P .^{43}$ All of the complexes have hydrophilic character with $\log P<0$. Furthermore, the results show that the incorporation of the extra $\mathrm{CH}_{2}$ group into the alkyl linker of the supporting cyclophane ligands does not result in a significant change in $\log P$ for the resultant Au-NHC complex. Incorporation of the extra aromatic rings in the benzimidazolederived complexes, however, resulted in a significant increase in hydrophobic character, as indicated by an increase in $\log P$ of $\sim 1$ unit.

Complexes cis-3·2Br and trans-3·2Br showed aqueous solution luminescence characteristics suitable for identifying their sub-cellular localization inside live cells. MDA-MB-231 (MDA) breast cancer cells were treated with cis-3.2Br (final concentration $26.2 \mu \mathrm{M}$ ) and the cells were visualized using a luminescence microscope for $6 \mathrm{~h}$ (UV illumination, one image recorded every $30 \mathrm{~s}$ ), and the time lapse movie of the cellular uptake and localization is provided in ESI (Movie S1†). No photo-bleaching of the luminescence originating from cis$3 \cdot 2 \mathrm{Br}$ was apparent over the duration of the experiment. Two images recorded $1 \mathrm{~h}$ and $3 \mathrm{~h}$ after initial exposure of cells to cis-3.2Br are shown in Fig. 8. There is increasing luminescence intensity from cells after addition of cis-3.2Br, an indication of cellular uptake of the luminescent Au-NHC complex. After $3 \mathrm{~h}$, the luminescence signal appeared punctate, and localised to small subcellular compartments, likely endosomes or lysosomes. In some of the cells there was a central region devoid of luminescence, suggesting that the compound does not accumulate in the nuclei of cells. Movie S1† shows remarkably

Table $3 \log P$ values determined for the cis isomers of the dinuclear Au(I) cyclophane complexes

\begin{tabular}{ll}
\hline Complex & $\log P$ \\
\hline cis-1·2Br & $-2.36 \pm 0.23$ \\
cis-2·2Br & $-2.35 \pm 0.21$ \\
cis-3·2Br & $-1.15 \pm 0.04$ \\
cis-4.2Br & $-1.10 \pm 0.06$
\end{tabular}
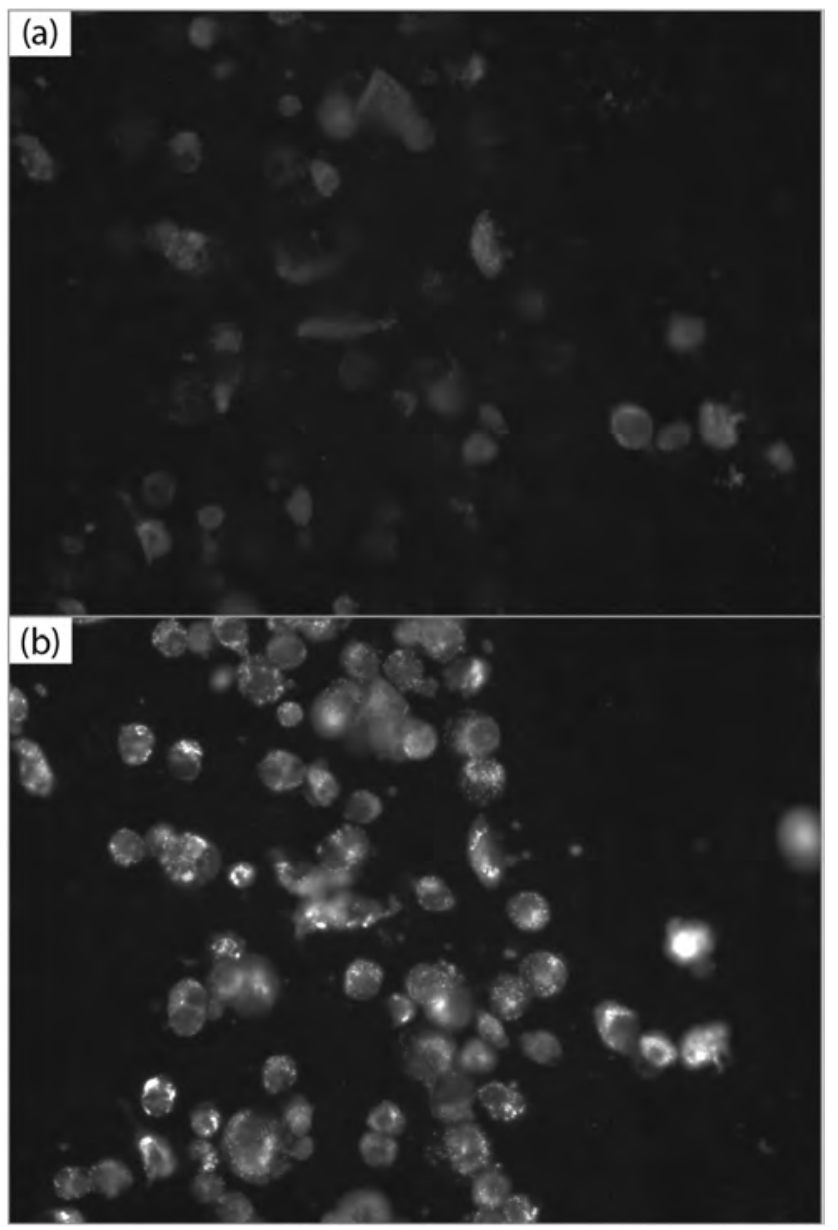

Fig. 8 Luminescence microscopy images of MDA-MB-231 cells (a) $1 \mathrm{~h}$ (b) $3 \mathrm{~h}$ after treatment with cis-3.2Br $(26.2 \mu \mathrm{M})$. No background fluorescence was observed before addition of cis-3.2Br.

detailed capture of the live cellular processes as the cells take up cis-3·2Br. After $1 \mathrm{~h}$, diffuse luminescence was seen originating from nearly all of the cells in the field of view, with very intense luminescence originating from some cells. After $3 \mathrm{~h}$, whilst the diffuse luminescence intensity remained throughout the cells, there was the accumulation of intense luminescence signal originating from small and highly mobile organelles. Whilst the organelles have not been identified in these experiments, our previous studies using cis-1.2Br $(100 \mu \mathrm{M})$ and $\mathrm{RAW}_{264.7}$ cells (15 h incubation) showed localization to lysosomes rather than mitochondria, suggesting that they are sequestered there for degradation. Notably the greater lipophilicity of $c i s-3 \cdot 2 \mathrm{Br}$ allowed cellular imaging studies to be carried out with a 4 -fold lower concentration and with luminescence visible in a much shorter timeframe (less than $1 \mathrm{~h}$ ).

\section{Conclusions}

In solution of their dibromide salts, the cyclophane cations $\mathbf{I}^{2+}-\mathbf{V}^{2+}$ were fluxional on the NMR timescale. For the $\mathrm{C}_{3}$-linked 
1 cyclophanes $\mathbf{I I}^{2+}$ and $\mathbf{I V}^{2+}$, fluxionality was due to interconversion of conformations in which the azolium groups were mutually syn. For the $\mathrm{C}_{4}$-linked cyclophanes $\mathbf{I I I}^{2+}$ and $\mathbf{V}^{2+}$, interconversion between conformations in solution occurred too rapidly for the individual conformations to be identified, but in the solid state both cyclophanes adopted conformations in which the azolium groups were mutually syn. For the $\mathrm{C}_{2}{ }^{-}$ linked cyclophane $\mathbf{I}^{2+}$, in solution and in the solid state, only conformations in which the imidazolium groups were mutually anti were detected.

The $\mathrm{C}_{2}$-linked cyclophane $\mathbf{I} \cdot 2 \mathrm{Br}$ could not be converted into a dinuclear complex of form $\mathrm{Au}_{2} \mathrm{~L}_{2}{ }^{2+}$, perhaps a consequence of $\mathbf{I}^{2+}$ (or its NHC derivatives) being unable to adopt a conformation in which the heterocyclic units are mutually syn. The $\mathrm{C}_{3}$ - and $\mathrm{C}_{4}$-linked cyclophanes were readily converted into the dinuclear Au-NHC complexes $\mathbf{1}^{2+}-\mathbf{4}^{2+}$, each of which existed as cis and trans isomers due to the asymmetry in the cyclophane structure. We have shown in this work that by appropriate ligand design, we have been able to construct complexes having short $\mathrm{Au} \cdots \mathrm{Au}$ contacts, between $\sim 2.9$ and $\sim 3.3 \AA$, indicative of an aurophilic interaction. ${ }^{29}$ In parallel, modification of the supporting cyclophane structure to incorporate less polar functional groups significantly influenced the lipophilicity of the complexes, to in turn influence membrane solubility of the complexes, and their cellular uptake and distribution patterns. The luminescent properties of $c i s-3 \cdot 2 \mathrm{Br}$ were exploited to map the distribution of the complex inside live tumour cells, without the need for an additional fluorescent tag, giving valuable insight into the sub-cellular distribution for this class of compounds. Notably the observation of intense fluorescence inside the cells over a period of $6 \mathrm{~h}$ indicates the integrity of the dinuclear complex (i.e. $\mathrm{Au}(\mathrm{I}) \cdots \mathrm{Au}(\mathrm{I})$ distance) remains intact and it is not degraded by in cellulo reactions with biological thiols, consistent with the lack of reactivity of cis$1 \cdot 2 \mathrm{Br}$ with glutathione. ${ }^{27}$ In turn, the low thiol reactivity is consistent with the low cytotoxicity of these dinuclear $\mathrm{Au}-$ NHC complexes, in comparison with mononuclear $\mathrm{Au}(\mathrm{I})-$ NHC complexes, where antitumour activity has been attributed to facile ligand exchange reactions with protein thiols and selenols, such as TrxR. ${ }^{24}$

Optical probes for use in biological systems should enter the cell quickly, cause minimal perturbation of the cell, maintain their integrity and remain emissive once inside the cell, and resist photofading/photobleaching. ${ }^{44}$ Since the luminescence signal originating from cis-3.2Br was resistant to photobleaching for more than $6 \mathrm{~h}$, and as cis-3.2Br was not significantly cytotoxic, complexes of this type may have potential applications as emissive molecular probes. Metal coordination complexes offer many advantages as cell penetrating optical probes, including design versatility not available in purely organic molecules. Fine-tuning the design of these Au-NHC complexes (for example by incorporation of peptide conjugates) ${ }^{45,46}$ provides ample scope to improve targeting of probes to specific cells or subcellular organelles.

\section{Experimental}

\section{General information}

All chemical reagents and solvents were obtained from commercial sources (Univar, Aldrich or Fluka) unless otherwise specified. Au powder was obtained from Precious Metals Online. Nuclear magnetic resonance spectra were recorded using Bruker ARX-300 (300.14 MHz for $\left.{ }^{1} \mathrm{H}\right)$, Bruker AV-500 (500.13 MHz for $\left.{ }^{1} \mathrm{H}\right)$, or Bruker AV-600 $\left(600.13 \mathrm{MHz}\right.$ for $\left.{ }^{1} \mathrm{H}\right)$ spectrometers at ambient temperature unless stated otherwise. ${ }^{1} \mathrm{H}$ NMR chemical shifts were referenced to solvent references. ${ }^{47}$ Microanalyses were performed by the Microanalytical Laboratory at the Research School of Chemistry, Australian National University, Canberra. Solvents for synthetic work were purified by distillation from the appropriate drying agent under nitrogen, and stored over sieves when necessary. ${ }^{48} \alpha, \alpha^{\prime}$ Dibromo-o-xylene, ${ }^{49}$ 1,2-bis( $N$-imidazolyl)ethane, ${ }^{50} \quad 1,3$-bis $(N$ imidazolyl)propane ${ }^{51} 1,4$-bis $\left(N\right.$-imidazolyl)butane, ${ }^{52} 1,3$-bis $(N$ benzimidazolyl)propane ${ }^{53}$ 1,4-bis $(N$-benzimidazolyl $)$ butane, ${ }^{53}$ II $\cdot 2 \mathrm{Br},{ }^{27}$ and $\left(\mathrm{Me}_{2} \mathrm{~S}\right) \mathrm{AuCl},{ }^{54}$ were prepared according to literature procedures. $\left(\mathrm{Me}_{2} \mathrm{~S}\right) \mathrm{AuBr}$ was prepared by the addition of $\mathrm{Me}_{2} \mathrm{~S}$ (2 equivalents) to $\mathrm{KAuBr}_{4}$ in a modification of the procedure used for $\left(\mathrm{Me}_{2} \mathrm{~S}\right) \mathrm{AuCl}$.

Synthesis of azolium cyclophane salts. I-2Br: Acetonitrile solutions $(150 \mathrm{~mL})$ of 1,2-bis( $N$-imidazolyl)ethane $(3 \mathrm{~g}$, $18.5 \mathrm{mmol}$ ) and $\alpha, \alpha^{\prime}$-dibromo-o-xylene $(4.88 \mathrm{~g}, 18.5 \mathrm{mmol})$ were added simultaneously and dropwise to refluxing acetonitrile $(450 \mathrm{~mL})$ over a period of $6 \mathrm{~h}$, and the mixture was left to reflux overnight. The resulting cloudy, white mixture was cooled to room temperature and filtered, and the solvent was removed under reduced pressure, yielding a white solid. Recrystallisation from ethanol yielded colourless crystals of I.2Br $(1.35 \mathrm{~g}, 27 \%)$, which were collected at the pump and washed with diethyl ether. ${ }^{1} \mathrm{H}$ NMR $\left(300.13 \mathrm{MHz}\right.$, DMSO-d $\left.\mathrm{d}_{6}\right): \delta$ $=7.98\left(\mathrm{t},{ }^{4} J_{\mathrm{HH}}=1.68 \mathrm{~Hz}, 2 \mathrm{H}\right.$, imidazolyl H2), $7.95\left(\mathrm{t},{ }^{3} J_{\mathrm{HH}}=1.7\right.$ $\mathrm{Hz}, 2 \mathrm{H}$, imidazolyl H4/5), 7.82-7.9 ( $\mathrm{m}, 2 \mathrm{H}$, xylyl ArH), 7.60-7.67 (m, 2H, xylyl ArH), $7.43\left(\mathrm{t},{ }^{3} \mathrm{~J}_{\mathrm{HH}}=1.7 \mathrm{~Hz}, 2 \mathrm{H}\right.$, imidazolyl H4/5) $5.72\left(\mathrm{~d},{ }^{2} J_{\mathrm{HH}}=14.4 \mathrm{~Hz}, 2 \mathrm{H}\right.$, xylyl $\left.\mathrm{CH} H\right), 5.62(\mathrm{~d}$, ${ }^{2} J_{\mathrm{HH}}=14.4 \mathrm{~Hz}, 2 \mathrm{H}$, xylyl $\mathrm{CHH}$ ), 4.77 (apparent d, splitting = $10.4 \mathrm{~Hz}, 2 \mathrm{H}, \mathrm{CH} H \mathrm{CH} H$ ), 4.22 (apparent d, splitting = $10.4 \mathrm{~Hz}$, $2 \mathrm{H}, \quad \mathrm{CH} H \mathrm{CH} H$ ). Elem. Anal.: Calcd for $\mathrm{C}_{16} \mathrm{H}_{18} \mathrm{~N}_{4} \mathrm{Br}_{2} \cdot 0.5 \mathrm{H}_{2} \mathrm{O} \cdot 0.5 \mathrm{CH}_{3} \mathrm{CH}_{2} \mathrm{OH}: \mathrm{C} 44.56, \mathrm{H} 4.83, \mathrm{~N} 12.22$. Found: C 44.66, H 4.65, N 12.54 .

III-2Br: Acetonitrile solutions $(50 \mathrm{~mL})$ of 1,4-bis $(N$-imidazolyl)butane $(0.95 \mathrm{~g}, 5.0 \mathrm{mmol})$ and $\alpha, \alpha^{\prime}$-dibromo-o-xylene $(1.3 \mathrm{~g}$, $5.0 \mathrm{mmol}$ ) were added simultaneously and dropwise to refluxing acetonitrile $(250 \mathrm{~mL})$ over a period of $6 \mathrm{~h}$, and the mixture was allowed to reflux for a further $72 \mathrm{~h}$, during which time a white insoluble solid deposited on the reaction flask. The mixture was filtered whilst hot to yield a clear yellow filtrate. The solvent was removed from the filtrate under reduced pressure to yield a white solid. Recrystallised from boiling ethanol afforded large colourless crystals of III. $2 \mathrm{Br}(1.27 \mathrm{~g}, 56 \%)$, which were collected at the pump and washed with cold diethyl ether. ${ }^{1} \mathrm{H}$ NMR (500.13 MHz, $\left.\mathrm{CD}_{3} \mathrm{OD}\right): \delta=7.80-7.84(\mathrm{~m}, 2 \mathrm{H}$, xylyl ArH), 7.70-7.74 (m, 2H, xylyl ArH), $7.54\left(\mathrm{~d},{ }^{3} J_{\mathrm{HH}}=2.0 \mathrm{~Hz}, 2 \mathrm{H}\right.$, imidazo- 
lyl H4/5), 7.48 (d, ${ }^{3} \mathrm{~J}_{\mathrm{HH}}=2.0 \mathrm{~Hz}, 2 \mathrm{H}$, imidazolyl H4/5), 5.69 (s, $4 \mathrm{H}$, xylyl $\mathrm{CH}_{2}$ ), 4.15 (apparent $\mathrm{t}$, splitting $=5 \mathrm{~Hz}, 4 \mathrm{H}$, $\mathrm{NCH}_{2} \mathrm{CH}_{2} \mathrm{CH}_{2} \mathrm{CH}_{2} \mathrm{~N}$ ), 1.98 (apparent quintet, splitting $=5 \mathrm{~Hz}$, $4 \mathrm{H}, \mathrm{NCH}_{2} \mathrm{CH}_{2} \mathrm{CH}_{2} \mathrm{CH}_{2} \mathrm{~N}$ ). The imidazolyl $\mathrm{H} 2$ proton was not seen due to $\mathrm{H} / \mathrm{D}$ exchange, but in $\mathrm{DMSO}-\mathrm{d}_{6}$ solution was seen as a singlet at $\delta$ 8.60. Elem. Anal.: Calcd for $\mathrm{C}_{18} \mathrm{H}_{22} \mathrm{~N}_{4} \mathrm{Br}_{2} \cdot 1.5 \mathrm{H}_{2} \mathrm{O}$ : C 44.93, H 5.23, N 11.64. Found: C 45.29, H 5.33, N 11.57.

IV-2Br: Acetonitrile solutions $(50 \mathrm{~mL})$ of 1,3-bis $(N$-benzimidazolyl)propane $(1.0 \mathrm{~g}, 35.7 \mathrm{mmol})$ and $\alpha, \alpha^{\prime}$-dibromo-o-xylene $(0.94 \mathrm{~g}, 35.0 \mathrm{mmol})$ were added simultaneously and dropwise to refluxing acetonitrile $(200 \mathrm{~mL})$ over a period of $6 \mathrm{~h}$, and the solution was allowed to reflux for a further $72 \mathrm{~h}$. The mixture was filtered whilst hot and the clear yellow filtrate was stripped of solvent under reduced pressure to yield a white solid. Recrystallisation from boiling ethanol gave colourless crystals of IV.2Br (1.68 g, 89\%), which were collected at the pump and washed with cold diethyl ether. ${ }^{1} \mathrm{H}$ NMR (500.13 MHz, DMSO$\left.\mathrm{d}_{6}\right): \delta=8.94(\mathrm{~s}, 2 \mathrm{H}$, benzimidazolyl H2), 7.90-7.94 (m, 2H, xylyl ArH), 7.79-7.85 (m, 2H, xylyl ArH), $7.88\left(\mathrm{dd},{ }^{3} \mathrm{~J}_{\mathrm{HH}}=8.0 \mathrm{~Hz},{ }^{4} \mathrm{~J}_{\mathrm{HH}}\right.$ $=0.8 \mathrm{~Hz}, 2 \mathrm{H}$, benzimidazolyl H4/7), $7.73\left(\mathrm{dd},{ }^{3} J_{\mathrm{HH}}=8.0 \mathrm{~Hz}\right.$, ${ }^{4} J_{\mathrm{HH}}=0.8 \mathrm{~Hz}, 2 \mathrm{H}$, benzimidazolyl $\left.\mathrm{H} 4 / 7\right), 7.36\left(\mathrm{dt},{ }^{3} J_{\mathrm{HH}}=8.0\right.$ $\mathrm{Hz},{ }^{4} \mathrm{~J}_{\mathrm{HH}}=0.8 \mathrm{~Hz}, 2 \mathrm{H}$, benzimidazolyl H5/6), $7.26\left(\mathrm{dt},{ }^{3} \mathrm{~J}_{\mathrm{HH}}=\right.$ $8.0 \mathrm{~Hz},{ }^{4} J_{\mathrm{HH}}=0.8 \mathrm{~Hz}, 2 \mathrm{H}$, benzimidazolyl H5/6), $6.18\left(\mathrm{~d},{ }^{2} \mathrm{~J}_{\mathrm{HH}}=\right.$ $14.6 \mathrm{~Hz}, 2 \mathrm{H}$, xylyl $\mathrm{CH}), 5.49\left(\mathrm{~d},{ }^{2} \mathrm{~J}_{\mathrm{HH}}=14.6 \mathrm{~Hz}, 2 \mathrm{H}\right.$ xylyl $\mathrm{CH}), \quad 4.75\left(\mathrm{~m}, 4 \mathrm{H}, \quad \mathrm{NCH}_{2} \mathrm{CH}_{2} \mathrm{CH}_{2} \mathrm{~N}\right), \quad 2.86(\mathrm{~m}, \quad 1 \mathrm{H}$, $\mathrm{NCH}_{2} \mathrm{CHHCH}_{2} \mathrm{~N}$ ), 2.34 (apparent d, splitting $=16.0 \mathrm{~Hz}, 1 \mathrm{H}$, $\mathrm{NCH}_{2} \mathrm{CH} H \mathrm{HCH}_{2} \mathrm{~N}$ ). Elem. Anal.: Calcd for $\mathrm{C}_{25} \mathrm{H}_{24} \mathrm{~N}_{4} \mathrm{Br}_{2} \cdot 2.5 \mathrm{H}_{2} \mathrm{O}$ : C 51.30, H 4.99, N 9.76. Found: C 51.67, H 4.95, N 9.76.

V.2Br: Acetonitrile solutions $(75 \mathrm{~mL})$ of 1,4-bis $(N$-benzimidazolyl)butane $(1.0 \mathrm{~g}, 3.4 \mathrm{mmol})$ and $\alpha, \alpha^{\prime}$-dibromo-o-xylene ( $0.9 \mathrm{~g}, 3.4 \mathrm{mmol}$ ) were added simultaneously and dropwise to refluxing acetonitrile $(200 \mathrm{~mL})$ over a period of $6 \mathrm{~h}$, and the mixture was allowed to reflux for a further $48 \mathrm{~h}$, during which time a white precipitate formed. The mixture was filtered whilst hot and the collected solid was suspended in boiling ethanol $(50 \mathrm{~mL})$ for $15 \mathrm{~min}$. The suspension was filtered whilst hot, and from the resulting yellow solution, large colourless crystals of $\mathbf{V} \cdot 2 \mathrm{Br}(0.53 \mathrm{~g}, 22 \%)$ were deposited upon cooling. The crystals were collected at the pump and washed with diethyl ether. ${ }^{1} \mathrm{H}$ NMR (500.13 MHz, DMSO- $\left.\mathrm{d}_{6}\right): \delta=8.96(\mathrm{~s}, 2 \mathrm{H}$, benzimidazolyl $\mathrm{H} 2$ ), 7.88-7.92 (m, 2H, xylyl ArH), 7.77-7.82 (m, 2H, xylyl ArH), 7.96 (d, ${ }^{3} J_{\mathrm{HH}}=8.5 \mathrm{~Hz}, 2 \mathrm{H}$, benzimidazolyl $\mathrm{H} 4 / 7$ ), 7.68 (d, ${ }^{3} J_{\mathrm{HH}}=8.5 \mathrm{~Hz}, 2 \mathrm{H}$, benzimidazolyl $\mathrm{H} 4 / 7$ ), 7.41 $\left(\mathrm{dt},{ }^{3} J_{\mathrm{HH}}=8.5 \mathrm{~Hz},{ }^{4} J_{\mathrm{HH}}=1.0 \mathrm{~Hz}, 2 \mathrm{H}\right.$, benzimidazolyl H5/6), $7.30\left(\mathrm{dt},{ }^{3} J_{\mathrm{HH}}=8.5 \mathrm{~Hz},{ }^{4} J_{\mathrm{HH}}=1.0 \mathrm{~Hz}, 2 \mathrm{H}\right.$, benzimidazolyl $\mathrm{H} 5 / 6$ ), 5.86 (br, 4H, xylyl $\mathrm{CH}_{2}$ ), 4.31 (br, $4 \mathrm{H}$, $\mathrm{NCH}_{2} \mathrm{CH}_{2} \mathrm{CH}_{2} \mathrm{CH}_{2} \mathrm{~N}$ ), 2.05 (br, $4 \mathrm{H}, \mathrm{NCH}_{2} \mathrm{CH}_{2} \mathrm{CH}_{2} \mathrm{CH}_{2} \mathrm{~N}$ ). Elem. Anal.: Calcd for $\mathrm{C}_{26} \mathrm{H}_{26} \mathrm{~N}_{4} \mathrm{Br}_{2} \cdot 0.5 \mathrm{H}_{2} \mathrm{O}$ : C 55.44, $\mathrm{H} 4.83, \mathrm{~N} 9.94$. Found: C 55.53, H 4.89, N 9.83.

Synthesis of Au-NHC complexes. 2.2Br: III-2Br (199 mg, $0.44 \mathrm{mmol})$ and $\left(\mathrm{Me}_{2} \mathrm{~S}\right) \mathrm{AuCl}(129 \mathrm{mg}, 0.44 \mathrm{mmol})$ were dissolved in hot DMF $\left(40 \mathrm{~mL}, 95^{\circ} \mathrm{C}\right)$. Sodium acetate $(0.11 \mathrm{~g}$, $1.3 \mathrm{mmol}$ ) was added and heating was continued for a further $24 \mathrm{~h}$, during which time a white precipitate formed. The mixture was allowed to cool, and the white precipitate was collected at the pump and washed with diethyl ether. The filtrate was poured into diethyl ether $(200 \mathrm{~mL})$ to produce a second white precipitate, which was collected at the pump and washed with acetone then diethyl ether. The first precipitate was recrystallised from boiling methanol and isopropanol $(5: 1)$ to give trans-2.2Br as colourless needles. These crystals were collected at the pump and washed with acetone $(11 \mathrm{mg}$, $4.4 \%)$. The second white precipitate that formed on addition of diethyl ether to the filtrate was recrystallised from boiling methanol/isopropanol $(5: 1)$ to give white microcrystals of cis$2 \cdot 2 \mathrm{Br}$, which were collected and washed with acetone $(28 \mathrm{mg}$, 11\%). cis-2·2Br: ${ }^{1} \mathrm{H}$ NMR (500.13 MHz, $\left.\mathrm{CD}_{3} \mathrm{OD}\right): \delta=7.75-7.79$ (m, 4H, xylyl ArH), 7.65-7.69 (m, 4H, xylyl ArH), $6.99\left(\mathrm{~d},{ }^{3} J_{\mathrm{HH}}=\right.$ $2.0 \mathrm{~Hz}, 4 \mathrm{H}$, imidazolyl H4/5), 6.65 (d, ${ }^{3} \mathrm{JHH}_{\mathrm{HH}}=2.0 \mathrm{~Hz}, 4 \mathrm{H}$, imidazolyl H4/5), 6.43 (d, ${ }^{2} J_{\mathrm{HH}}=14.0 \mathrm{~Hz}, 4 \mathrm{H}$, xylyl CHH), 5.26 (d, ${ }^{2} J_{\mathrm{HH}}=14.0 \mathrm{~Hz}, 4 \mathrm{H}$, xylyl CHH$), 4.42\left(\mathrm{dd},{ }^{2} J_{\mathrm{HH}}=14.5 \mathrm{~Hz},{ }^{3} J_{\mathrm{HH}}=\right.$ $7.0 \mathrm{~Hz}, 4 \mathrm{H}, \mathrm{NCH} \mathrm{HCH}_{2} \mathrm{CH}_{2} \mathrm{CHHN}$ ), 4.05 (dd, ${ }^{2} J=14.5 \mathrm{~Hz},{ }^{3} J=$ $\left.7.0 \mathrm{~Hz}, \quad 4 \mathrm{H}, \quad \mathrm{NCH} \mathrm{CH}_{2} \mathrm{CH}_{2} \mathrm{CH} H \mathrm{~N}\right), \quad 2.94(\mathrm{~m}, \quad 4 \mathrm{H}$, $\left.\mathrm{NCH}_{2} \mathrm{CHHCH} \mathrm{HCH}_{2} \mathrm{~N}\right), 2.16\left(\mathrm{~m}, 4 \mathrm{H}, \mathrm{NCH}_{2} \mathrm{CH} H \mathrm{CH} H \mathrm{CH}_{2} \mathrm{~N}\right)$. Elem. Anal.: Calcd for $\mathrm{C}_{36} \mathrm{H}_{40} \mathrm{Au}_{2} \mathrm{~N}_{8} \mathrm{Br}_{2}\left(\mathrm{H}_{2} \mathrm{O}\right)_{3}$ : C 36.26, H 3.89, N 9.39. Found: C 36.38, H 3.94, N 9.30.

To ensure incorporation of bromide as the counter ion, a sample of trans-2.2Br was prepared in a procedure analogous to that above, from sodium acetate (145 mg, $177 \mathrm{mmol})$, III. $2 \mathrm{Br}(267 \mathrm{mg}, 0.59 \mathrm{mmol})$ and $\left(\mathrm{Me}_{2} \mathrm{~S}\right) \mathrm{AuBr}(200 \mathrm{mg}$, $0.59 \mathrm{mmol}$ ) in DMF at $95{ }^{\circ} \mathrm{C}$. The mixture was stirred at $95{ }^{\circ} \mathrm{C}$ for a further $3.5 \mathrm{~h}$, during which time a white precipitate appeared. Diethyl ether $(200 \mathrm{~mL})$ was added to the reaction mixture after brief cooling, and the precipitate was collected and washed with diethyl ether. The precipitate was recrystallised from a boiling mixture of methanol $(50 \mathrm{~mL})$ and isopropanol $(1 \mathrm{~mL})$ to yield trans-2.2Br as a white powder $(33 \mathrm{mg}$, 9.9\%) which was collected and washed with diethyl ether. trans-2·2Br: ${ }^{1} \mathrm{H}$ NMR (500.13 MHz, $\left.\mathrm{CD}_{3} \mathrm{OD}\right): \delta=7.79-7.84(\mathrm{~m}$, $4 \mathrm{H}$, xylyl ArH), 7.70-7.76 (m, 4H, xylyl ArH), 7.01 (d, ${ }^{3} J_{\mathrm{HH}}=2.0$ $\mathrm{Hz}, 4 \mathrm{H}$, imidazolyl H4/5), 6.47 (d, ${ }^{3} \mathrm{~J}_{\mathrm{HH}}=2.0 \mathrm{~Hz}, 4 \mathrm{H}$, imidazolyl $\mathrm{H} 4 / 5), 6.20\left(\mathrm{~d},{ }^{2} J_{\mathrm{HH}}=14.0 \mathrm{~Hz}, 4 \mathrm{H}\right.$, xylyl CHH$), 5.31\left(\mathrm{~d},{ }^{2} J_{\mathrm{HH}}=\right.$ $14.0 \mathrm{~Hz}, 4 \mathrm{H}$, xylyl $\mathrm{CH} H), 4.49\left(\mathrm{dd},{ }^{2} J_{\mathrm{HH}}=14.0 \mathrm{~Hz},{ }^{3} J_{\mathrm{HH}}=7.0\right.$ $\left.\mathrm{Hz}, 4 \mathrm{H}, \mathrm{NCHHCH} \mathrm{CH}_{2} \mathrm{CHHN}\right), 4.04\left(\mathrm{dd},{ }^{2} J_{\mathrm{HH}}=14.0 \mathrm{~Hz},{ }^{3} J_{\mathrm{HH}}=\right.$ $\left.7.0 \mathrm{~Hz}, \quad 4 \mathrm{H}, \quad \mathrm{NCH} \mathrm{CH}_{2} \mathrm{CH}_{2} \mathrm{CH} H \mathrm{~N}\right), \quad 3.01(\mathrm{~m}, \quad 4 \mathrm{H}$, $\left.\mathrm{NCH}_{2} \mathrm{CHHCH} \mathrm{HCH}_{2} \mathrm{~N}\right), 2.20\left(\mathrm{~m}, 4 \mathrm{H}, \mathrm{NCH}_{2} \mathrm{CH} H \mathrm{CH} \mathrm{CCH}_{2} \mathrm{~N}\right)$. Elem. Anal.: Calcd for $\mathrm{C}_{36} \mathrm{H}_{40} \mathrm{Au}_{2} \mathrm{~N}_{8} \mathrm{Br}_{2}$ : C 37.98, H 3.54, N 9.84. Found: C 37.78, H 3.76, N 9.64.

3.2Br: IV.2Br (226 mg, $0.42 \mathrm{mmol})$ and $\left(\mathrm{Me}_{2} \mathrm{~S}\right) \mathrm{AuBr}$ (140 mg, $0.42 \mathrm{mmol}$ ) were dissolved in hot DMF $(40 \mathrm{~mL}$, $\left.110{ }^{\circ} \mathrm{C}\right)$. Sodium acetate $(120 \mathrm{mg}, 1.48 \mathrm{mmol})$ was added and heating was continued at $110{ }^{\circ} \mathrm{C}$ for a further $2 \mathrm{~h}$ during, which time a pale yellow precipitate formed. The precipitate was collected whilst still hot, and the filtrate preserved. The precipitate was washed once with water and then with diethyl ether, and recrystallised from boiling methanol to yield a crop of large pale yellow crystals of cis-3.2Br (16 mg, 6\%), which were collected by filtration through a pore 1 glass frit. Further standing of the mother liquor yielded small yellow needles of cis-3.2Br (29 mg, 10\%, total yield 16\%). The crude reaction filtrate was allowed to cool and diethyl ether $(150 \mathrm{~mL})$ was added. The resulting fine, vivid yellow precipitate was collected 
at the pump and dissolved in boiling methanol $(25 \mathrm{~mL})$ and DMSO (3 mL) and filtered whilst hot, and the volume of the filtrate was reduced to $\sim 12 \mathrm{~mL}$. Upon cooling, trans-3·2Br was deposited as a fine yellow powder $(23 \mathrm{mg}, 8.2 \%)$, which was collected and washed with diethyl ether.

cis-3·2Br: ${ }^{1} \mathrm{H}$ NMR (500.13 MHz, DMSO-d $\left.{ }_{6}\right): \delta=8.11-8.25$ (m, 4H, xylyl ArH), 6.69-7.82 (m, 4H, xylyl ArH), 7.54 (d, ${ }^{3} J_{\mathrm{HH}}=$ $8.3 \mathrm{~Hz}, 4 \mathrm{H}$, benzimidazolyl $\mathrm{H} 4 / 7), 6.72\left(\mathrm{~d},{ }^{3} J_{\mathrm{HH}}=8.3 \mathrm{~Hz}, 4 \mathrm{H}\right.$, benzimidazolyl H4/7), $7.00\left(\mathrm{dd},{ }^{3} J_{\mathrm{HH}}=7.8 \mathrm{~Hz},{ }^{3} J_{\mathrm{HH}}=8.3 \mathrm{~Hz}\right.$, $4 \mathrm{H}$, benzimidazolyl $\mathrm{H} 5 / 6), 6.71\left(\mathrm{dd},{ }^{3} J_{\mathrm{HH}}=7.8 \mathrm{~Hz},{ }^{3} J_{\mathrm{HH}}=8.3\right.$ $\mathrm{Hz}, 4 \mathrm{H}$, benzimidazolyl H5/6), 6.79 (d, ${ }^{2} J_{\mathrm{HH}}=14.5 \mathrm{~Hz}, 4 \mathrm{H}$, xylyl $\mathrm{CHH}), 5.72\left(\mathrm{~d},{ }^{2} J_{\mathrm{HH}}=14.5 \mathrm{~Hz}, 4 \mathrm{H}\right.$ xylyl $\left.\mathrm{CHH}\right), 5.50(\mathrm{~m}, 4 \mathrm{H}$, $\left.\mathrm{NCHHCH}_{2} \mathrm{CHHN}\right), 5.00\left(\mathrm{~m}, 4 \mathrm{H}, \mathrm{NCHHCH}_{2} \mathrm{CH} H \mathrm{~N}\right), 2.71(\mathrm{~m}$, $\left.2 \mathrm{H}, \mathrm{NCH}_{2} \mathrm{CH} H \mathrm{CH}_{2} \mathrm{~N}\right), \sim 2.49\left(\mathrm{NCH}_{2} \mathrm{CHHCH}_{2} \mathrm{~N}\right.$; obscured by solvent). Elem. Anal.: Calcd for $\mathrm{Au}_{2} \mathrm{C}_{50} \mathrm{H}_{44} \mathrm{~N}_{8} \mathrm{Br}_{2} \cdot \mathrm{CH}_{3} \mathrm{OH}$ : C 45.62, H 3.60, N 8.35. Found: C 45.58, H 3.22, N 8.40.

trans-3.2Br: ${ }^{1} \mathrm{H}$ NMR $\left(500.13 \mathrm{MHz}\right.$, DMSO-d $\left.\mathrm{d}_{6}\right): \delta=8.20-8.30$ (m, 4H, xylyl ArH), 7.80-7.90 (m, 4H, xylyl ArH), $7.51\left(\mathrm{~d},{ }^{3} J_{\mathrm{HH}}=\right.$ $8.5 \mathrm{~Hz}, 4 \mathrm{H}$, benzimidazolyl H4/7), $6.95\left(\mathrm{t},{ }^{3} J_{\mathrm{HH}}=7.5 \mathrm{~Hz},{ }^{3} \mathrm{~J}_{\mathrm{HH}}=\right.$ $8.5 \mathrm{~Hz}, 4 \mathrm{H}$, benzimidazolyl H5/6), $6.78\left(\mathrm{t},{ }^{3} \mathrm{~J}_{\mathrm{HH}}=7.5 \mathrm{~Hz},{ }^{3} \mathrm{~J}_{\mathrm{HH}}=\right.$ $8.5 \mathrm{~Hz}, 4 \mathrm{H}$, benzimidazolyl $\mathrm{H} 5 / 6), 6.74\left(\mathrm{~d}, 4 \mathrm{H}, \mathrm{H} 4 / \mathrm{H} 7,{ }^{3} \mathrm{~J}_{\mathrm{HH}}=\right.$ $8.5 \mathrm{~Hz}$, benzimidazolyl H4/7), $6.73\left(\mathrm{~d},{ }^{2} J_{\mathrm{HH}}=14.5 \mathrm{~Hz}, 4 \mathrm{H}\right.$, xylyl $\mathrm{CHH}), 5.82\left(\mathrm{~d},{ }^{2} J_{\mathrm{HH}}=14.5 \mathrm{~Hz}, 4 \mathrm{H}\right.$, xylyl $\left.\mathrm{CH} H\right), 5.51(\mathrm{~m}, 4 \mathrm{H}$, $\left.\mathrm{NCH} \mathrm{HCH}_{2} \mathrm{CHHN}\right), 4.91$ (m, 4H, $\left.\mathrm{NCH} H C H_{2} \mathrm{CH} H \mathrm{~N}\right), \sim 2.49$ $\left(\mathrm{NCH}_{2} \mathrm{CH}_{2} \mathrm{CH}_{2} \mathrm{~N}\right.$; obscured by solvent). Elem. Anal.: Calcd for $\mathrm{Au}_{2} \mathrm{C}_{50} \mathrm{H}_{44} \mathrm{~N}_{8} \mathrm{Br}_{2} \cdot 6.5 \mathrm{H}_{2} \mathrm{O}$ : C $42.06, \mathrm{H} 4.02, \mathrm{~N}$ 7.85. Found: $\mathrm{C}$ $42.11, \mathrm{H} 3.88, \mathrm{~N} 7.89$.

4.2Br: $\mathrm{V} \cdot 2 \mathrm{Br}(248 \mathrm{mg}, 0.45 \mathrm{mmol})$ and $(\mathrm{Me})_{2} \mathrm{SAuBr}(159 \mathrm{mg}$, $0.47 \mathrm{mmol}$ ) were dissolved in hot DMF $\left(40 \mathrm{~mL}, 95^{\circ} \mathrm{C}\right)$. Sodium acetate $(148 \mathrm{mg}, 1.8 \mathrm{mmol}$ ) was added and heating was continued for $24 \mathrm{~h}$, during which time a pale yellow precipitate formed. The mixture was allowed to cool briefly and the precipitate was collected and the filtrate was kept. The precipitate was dissolved in boiling ethanol/methanol $(2: 1)$, and after hot filtration was concentrated and allowed to cool, upon which a fine white powder formed. This powder was recrystallised from boiling methanol to give trans-4.2Br as a white powder $(16 \mathrm{mg}$, $4.6 \%)$ which was collected at the pump and washed with diethyl ether. Diethyl ether $(200 \mathrm{~mL})$ was added to the filtrate (kept from above) and the resulting white powder was recrystallised from boiling methanol to yield cis-4.2Br as colourless needles (31 mg, 8.8\%) in two crops, which were collected at the pump and washed with diethyl ether.

cis-4.2Br: ${ }^{1} \mathrm{H}$ NMR (500.13 MHz, DMSO-d 6 ): $\delta=8.14-8.21$ (m, 4H, xylyl ArH), 7.77-7.84 (m, 4H, xylyl ArH), $7.43\left(\mathrm{~d},{ }^{3} J_{\mathrm{HH}}=\right.$ $8.0 \mathrm{~Hz}, 4 \mathrm{H}$, benzimidazolyl $\mathrm{H} 4 / 7), 6.94\left(\mathrm{t},{ }^{3} J_{\mathrm{HH}}=8.0 \mathrm{~Hz}, 4 \mathrm{H}\right.$, benzimidazolyl H5/6), $6.74\left(\mathrm{t},{ }^{3} \mathrm{~J}_{\mathrm{HH}}=8.0 \mathrm{~Hz}, 4 \mathrm{H}\right.$, benzimidazolyl $\mathrm{H} 5 / 6), 6.58\left(\mathrm{~d},{ }^{3} \mathrm{~J}_{\mathrm{HH}}=8.5 \mathrm{~Hz}, 4 \mathrm{H}\right.$, benzimidazolyl H4/7), 6.83 (d, ${ }^{2} J_{\mathrm{HH}}=14.0 \mathrm{~Hz}, 4 \mathrm{H}$, xylyl CHH), $5.78\left(\mathrm{~d},{ }^{2} J_{\mathrm{HH}}=14.0 \mathrm{~Hz}, 4 \mathrm{H}, \mathrm{xylyl}\right.$ $\mathrm{CH} H), 4.50-4.68\left(\mathrm{~m}, 8 \mathrm{H}, \mathrm{NCH}_{2} \mathrm{CH}_{2} \mathrm{CH}_{2} \mathrm{CH}_{2} \mathrm{~N}\right), 3.09(\mathrm{br}, 4 \mathrm{H}$, $\mathrm{NCH}_{2} \mathrm{CH} H \mathrm{CH} H \mathrm{CH}_{2} \mathrm{~N}$ ), 2.36 (br, $4 \mathrm{H}, \mathrm{NCH}_{2} \mathrm{C} H \mathrm{HC} H \mathrm{HCH}_{2} \mathrm{~N}$ ). Elem. Anal.: Calcd for $\mathrm{Au}_{2} \mathrm{C}_{52} \mathrm{H}_{48} \mathrm{~N}_{8} \mathrm{Br}_{2} \cdot 7 \mathrm{H}_{2} \mathrm{O}$ : C 42.64, $\mathrm{H} 4.26, \mathrm{~N}$ 7.65. Found: C 42.4, H 3.85, N 7.29.

trans-4.2Br: ${ }^{1} \mathrm{H}$ NMR $\left(500.13 \mathrm{MHz}\right.$, DMSO- $\left.\mathrm{d}_{6}\right): \delta=8.20-8.25$ (m, 4H, xylyl ArH), 7.85-7.92 (m, 4H, xylyl ArH), $7.41\left(\mathrm{~d},{ }^{3} J_{\mathrm{HH}}=\right.$ $8.5 \mathrm{~Hz}, 4 \mathrm{H}$, benzimidazolyl H4/7), $6.94\left(\mathrm{t},{ }^{3} \mathrm{~J}_{\mathrm{HH}}=8.5 \mathrm{~Hz},{ }^{3} J_{\mathrm{HH}}=\right.$
$8.0 \mathrm{~Hz}, 4 \mathrm{H}$, benzimidazolyl H5/67), $6.75\left(\mathrm{t},{ }^{3} J_{\mathrm{HH}}=8.5 \mathrm{~Hz},{ }^{3} J_{\mathrm{HH}}\right.$ $=8.0 \mathrm{~Hz}, 4 \mathrm{H}$, benzimidazolyl $\mathrm{H} 5 / 6), 6.53\left(\mathrm{~d},{ }^{3} J_{\mathrm{HH}}=8.5 \mathrm{~Hz}, 4 \mathrm{H}\right.$, benzimidazolyl H4/7), $6.64\left(\mathrm{~d},{ }^{2} J_{\mathrm{HH}}=14.5 \mathrm{~Hz}, 4 \mathrm{H}\right.$, xylyl CHH), $5.89\left(\mathrm{~d},{ }^{2} J_{\mathrm{HH}}=14.5 \mathrm{~Hz}, 4 \mathrm{H}\right.$, xylyl $\left.\mathrm{C} H \mathrm{H}\right), 4.48-4.69(\mathrm{~m}, 8 \mathrm{H}$, $\mathrm{NCH}_{2} \mathrm{CH}_{2} \mathrm{CH}_{2} \mathrm{CH}_{2} \mathrm{~N}$ ), 3.10 (br, $4 \mathrm{H}, \mathrm{NCH}_{2} \mathrm{CH} H \mathrm{CH} H \mathrm{CH}_{2} \mathrm{~N}$ ), 2.30 (br, 4H, $\mathrm{NCH}_{2} \mathrm{CH} H C H \mathrm{HCH}_{2} \mathrm{~N}$ ). Elem. Anal.: Calcd for $\mathrm{Au}_{2} \mathrm{C}_{52} \mathrm{H}_{48} \mathrm{~N}_{8} \mathrm{Br}_{2} \cdot\left(\mathrm{CH}_{3} \mathrm{OH}\right)_{2}\left(\mathrm{H}_{2} \mathrm{O}\right)_{2}$ : C $45.08, \mathrm{H}$ 4.20, N 7.78 . Found: C 45.38, H 4.03, N 7.62.

\section{Crystallographic studies}

Crystals of cis-2. $\mathrm{BrCl} \cdot 3 \mathrm{H}_{2} \mathrm{O}$ and trans$2 \cdot \mathrm{Br}_{0.75} \mathrm{Cl}_{1.25} \cdot 4 \mathrm{MeOH} \cdot 2 \mathrm{H}_{2} \mathrm{O}$ suitable for X-ray diffraction were obtained from samples of the Au-NHC complexes prepared from $\mathbf{I V} \cdot 2 \mathrm{Br}$ and $\left(\mathrm{CH}_{3}\right)_{2} \mathrm{SAuCl}$, followed by recrystallisation from hot methanolic solutions by addition of isopropanol. Crystals of $c i s-3 \cdot 2 \mathrm{Br} \cdot 2 \mathrm{MeOH} \cdot 3 \mathrm{H}_{2} \mathrm{O}$ suitable for diffraction were obtained by diffusion of diethyl ether vapour into a concentrated methanol solution of cis-3.2Br. All attempts to obtain crystals of trans-3.2Br resulted in crystals that were too small for diffraction, or which lost solvent too rapidly. Crystals of cis$4 \cdot 2 \mathrm{Br} \cdot 2 \mathrm{MeOH}$ and trans-4.2Br.3MeOH suitable for X-ray diffraction studies were obtained by the slow cooling of a concentrated methanol solution of cis-4.2Br and diffusion of diethyl ether vapour into a concentrated methanol/DMSO solution trans-4.2Br, respectively.

X-Ray diffraction data were collected on an Oxford diffraction Xcalibur diffractometer (Oxford Diffraction Gemini for cis$3 \cdot 2 \mathrm{Br} \cdot 2 \mathrm{MeOH} \cdot 3 \mathrm{H}_{2} \mathrm{O}$, Bruker Smart diffractometer for II $2 \mathrm{Br} \cdot \mathrm{C}_{3} \mathrm{H}_{6} \mathrm{O} \cdot \mathrm{H}_{2} \mathrm{O}$ ) fitted with Mo K $\alpha$ radiation. The data for I $2 \mathrm{Br} \cdot 2 \mathrm{H}_{2} \mathrm{O}$ were collected on a synchrotron. All of the structures presented have probability ellipsoids drawn at the $50 \%$ level $\left(30 \%\right.$ level for $\mathbf{I V} \cdot 2 \mathrm{Br} \cdot \mathrm{CH}_{3} \mathrm{CH}_{2} \mathrm{OH}$ and trans$4 \cdot 2 \mathrm{Br} \cdot 3 \mathrm{MeOH})$. Crystallographic data for the structures were collected at $100(2) \mathrm{K}\left(150(2) \mathrm{K}\right.$ for $\mathbf{I I} \cdot 2 \mathrm{Br} \cdot \mathrm{C}_{3} \mathrm{H}_{6} \mathrm{O} \cdot \mathrm{H}_{2} \mathrm{O}$ and IV $\cdot 2 \mathrm{Br} \cdot \mathrm{CH}_{3} \mathrm{CH}_{2} \mathrm{OH}, 103 \mathrm{~K}$ for $\mathbf{I} \cdot 2 \mathrm{Br} \cdot 2 \mathrm{H}_{2} \mathrm{O}$ ). Following multiscan absorption corrections (analytical for cis$3 \cdot 2 \mathrm{Br} \cdot 2 \mathrm{MeOH} \cdot 3 \mathrm{H}_{2} \mathrm{O}$ ) and solution by direct methods, the structures were refined against $F^{2}$ with full-matrix least-squares using the programs SHELXL-97 or SHELX-2014. ${ }^{55}$ CCDC 834016 (I·2Br), 834017 (II·2Br), 834018 (III-2Br), 834019 $(\mathrm{IV} \cdot 2 \mathrm{Br}), 834020 \quad(\mathrm{~V} \cdot 2 \mathrm{Br}), 834021$ (cis-2·BrCl$\left.\cdot 3 \mathrm{H}_{2} \mathrm{O}\right), 834022$

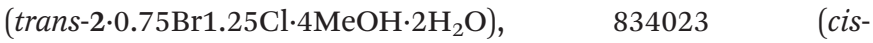
$\left.3 \cdot 2 \mathrm{Br} \cdot 2 \mathrm{MeOH} \cdot 3 \mathrm{H}_{2} \mathrm{O}\right), 834024($ cis $-4 \cdot 2 \mathrm{Br} \cdot 2 \mathrm{MeOH})$ and 834025 (trans-4.2Br-3MeOH) contain the supplementary crystallographic data for this paper.

\section{Crystal data and structure refinement}

I $2 \mathrm{Br} \cdot 2 \mathrm{H}_{2} \mathrm{O} . M=462.20$, orthorhombic, space group $P 2_{1} 2_{1} 2_{1}, a$ $=8.1485(6), b=14.5332(12), c=15.4360(13) \AA, V 1828.0(3) \AA^{3}, Z$ $4, \rho_{\text {calcd }} 1.679 \mathrm{Mg} \mathrm{m}^{-3}, \lambda 0.48595 \AA, \mu 2.389 \mathrm{~mm}^{-1}$, reflections collected 26940 , independent reflections 5197 [R(int) = 0.0587], max./min. transmission 1.00/0.80, data/restraint$\mathrm{s} /$ parameters $5197 / 6 / 231$. GoF 1.028. Final $R$ indices $[I>2 \sigma(I)]$ $R_{1}=0.0281, \mathrm{w} R_{2}=0.0618 ; R$ indices (all data) $R_{1}=0.0329, \mathrm{w} R_{2}$ $=0.0635$. Absolute structure parameter 0.13(2). Largest diff. peak and hole 0.984 and -0.424 e $\AA^{-3}$. 
II $\cdot 2 \mathrm{Br} \cdot \mathrm{C}_{3} \mathrm{H}_{6} \mathrm{O} \cdot \mathrm{H}_{2} \mathrm{O} . M=516.28$, triclinic, space group $P \overline{1} a=$ 9.2891(14), $b=11.4501(17), c=11.666(2) \AA, \alpha=104.754(2), \beta=$ 111.067(2), $\gamma=92.096(2)^{\circ}, V 1108.4(3) \AA^{3}, Z 2, \rho_{\text {calcd }} 1.547 \mathrm{Mg}$ $\mathrm{m}^{-3}, \lambda 0.71073 \AA$ А $\mu 3.679 \mathrm{~mm}^{-1}$, reflections collected 10429 , independent reflections $5339[R(\mathrm{int})=0.032]$, max. $/ \mathrm{min}$. transmission 1.00/0.84, data/restraints/parameters 5339/2/290. GoF 1.056. Final $R$ indices $[I>2 \sigma(I)]: R_{1}=0.0413, \mathrm{w} R_{2}=0.0876 ; R$ indices (all data): $R_{1}=0.0678, \mathrm{w} R_{2}=0.0968$. Largest diff. peak

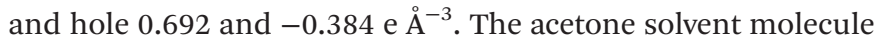
was modelled as being disordered over two sets of sites with site occupancies of the two components refined to $0.668(5)$ and its complement.

III $2 \mathrm{Br} . M=454.22$, monoclinic, space group $P 2_{1} / c, a=$ 9.1040(4), $b=12.7208(6), c=15.8340(10) \AA, \beta=101.216(5)^{\circ}, V$ 1798.72(17) $\AA^{3}, Z 4, \rho_{\text {calcd }} 1.677 \mathrm{Mg} \mathrm{m}^{-3}, \lambda 0.71073 \AA, \mu$ $4.514 \mathrm{~mm}^{-1}$, reflections collected 40296 , independent reflections $5046[R(\mathrm{int})=0.0301]$, max./min. transmission 1.21/0.74, data/restraints/parameters: 5046/0/217. GoF 1.012. Final $R$ indices $[I>2 \sigma(I)]: R_{1}=0.0307, \mathrm{w} R_{2}=0.0808 ; R$ indices (all data): $R_{1}=0.0439, \mathrm{w} R_{2}=0.0837$. Largest diff. peak and hole 1.640 and $-0.796 \mathrm{e}^{-3}$.

IV $\cdot 2 \mathrm{Br} \cdot \mathrm{CH}_{3} \mathrm{CH}_{2} \mathrm{OH} . \quad M=586.37$, monoclinic, space group $P 2_{1} / c, a=9.578(2), b=22.0948(17), c=13.560(2) \AA, \beta=90.175(17)^{\circ}$, $V$ 2869.6(8) $\AA^{3}, Z 4, \rho_{\text {calcd }} 1.357 \mathrm{Mg} \mathrm{m}^{-3}, \lambda 0.71073 \AA, \mu$ $2.849 \mathrm{~mm}^{-1}$, reflections collected 51143 , independent reflections $6588[R(\mathrm{int})=0.0550]$, max./min. transmission 1.00/0.51, data/restraints/parameters $6588 / 289 / 346$. GoF 1.051. Final $R$ indices $[I>2 \sigma(I)]: R_{1}=0.0804, \mathrm{w} R_{2}=0.2280 ; R$ indices (all data): $R_{1}=0.1052, \mathrm{w} R_{2}=0.2403$. Largest diff. peak and hole 1.353 and -1.071 e $\AA^{-3}$. One bromine atom was modelled as being disordered over two sites with occupancies refined to $0.806(3)$ and its complement. One solvent ethanol molecule is disordered about an inversion centre.

V.2Br. $M=554.33$, monoclinic, space group $P 2_{1} / n, a=$ 12.6464(10), $b=13.5603(10), c=13.6869(10) \AA, \beta=97.140(9)^{\circ}$, $V$ 2329.0(3) $\AA^{3}, Z 4, \rho_{\text {calcd }} 1.581 \mathrm{Mg} \mathrm{m}^{-3}, \lambda 0.71073 \AA$, $\mu$ $3.503 \mathrm{~mm}^{-1}$, reflections collected 64688 , independent reflections $7480[R(\mathrm{int})=0.0433]$, max./min. transmission $1.22 / 0.58$, data/restraints/parameters 7480/0/308. GoF 0.983. Final $R$ indices $[I>2 \sigma(I)] R_{1}=0.0506, \mathrm{w} R_{2}=0.1450 ; R$ indices (all data) $R_{1}=0.0813, \mathrm{w} R_{2}=0.1562$. Largest diff. peak and hole 2.049

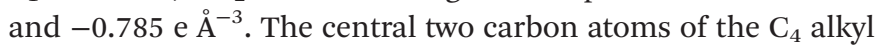
chain were modelled as being disordered over two sets of sites with occupancies set at 0.5 after trial refinement.

cis-2 $\cdot \mathrm{BrCl} \cdot 3 \mathrm{H}_{2} \mathrm{O} . M=1148.10$, orthorhombic, space group $P m 2_{1}, a=14.5133(5), b=7.1167(2), c=19.1502(5) \AA, V 1977.96$ (10) $\AA^{3}, Z 2, \rho_{\text {calcd }} 1.928 \mathrm{Mg} \mathrm{m}^{-3}, \lambda 0.71073 \AA, \mu 8.532 \mathrm{~mm}^{-1}$, reflections collected 27729 , independent reflections 6523 $[R$ (int $)=0.0789]$, max./min. transmission 1.00/0.38, data/restraints/parameters $6523 / 1 / 239$. GoF 1.008. Final $R$ indices $[I>2 \sigma(I)]: R_{1}=0.0603, \mathrm{w} R_{2}=0.1367 ; R$ indices (all data): $R_{1}=$ $0.0975, \mathrm{w} R_{2}=0.1462$. Absolute structure parameter 0.062(19).

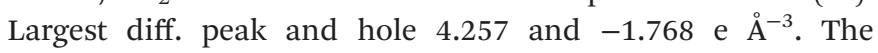
anionic sites were modelled as being occupied partially by chloride and bromide ions (for site (1)), or bromide and water (site (2)), or chlorine and water (site (3)) with occupancies set at 0.5 after trial refinement. Other peaks in the difference maps were modelled as being water molecules with occupancies set at either 1.0 or 0.5 after trial refinement and considerations of molecular interactions.

trans $-2 \cdot 0.75 \mathrm{Br} \cdot 1.25 \mathrm{Cl} \cdot 4 \mathrm{MeOH} \cdot 2 \mathrm{H}_{2} \mathrm{O} . \quad M=1247.14$, triclinic, space group $P \overline{1}, a=8.1215(5), b=11.4030(10), c=11.959(3) \AA$, $\alpha=84.260(10), \beta=82.030(10), \gamma=78.157(7)^{\circ}, V 1070.5(3) \AA^{3}, Z$ 1, $\rho_{\text {calcd }} 1.934 \mathrm{Mg} \mathrm{m}^{-3}, \lambda 71073 \AA, \mu 7.678 \mathrm{~mm}^{-1}$, reflections collected 49142, independent reflections 10859 [R(int) = $0.0374]$, max./min. transmission $1.00 / 0.40$, data/restraints/parameters $10859 / 3 / 275$. GoF 1.017. Final $R$ indices $[I>$ $2 \sigma(I)]: R_{1}=0.0227, \mathrm{w} R_{2}=0.0403 ; R$ indices (all data): $R_{1}=$ $0.0320, \mathrm{w}_{2}=0.0416$. Largest diff. peak and hole 4.395 and -1.041 e $\AA^{-3}$. The halide site was modelled as being occupied part by bromine and part chlorine with the occupancies refining to $\mathrm{Cl} 0.624(2), \mathrm{Br} 1-0.624(2)$.

cis-3.2Br$\cdot 2 \mathrm{MeOH} \cdot 3 \mathrm{H}_{2} \mathrm{O} . M=1428.82$, triclinic, space group $P \overline{1}, a=12.9166(3), b=14.7735(3), c=15.8256(3) \AA, ~ \alpha=114.049(2)$, $\beta=95.802(2), \gamma=109.275(2)^{\circ}, V 2504.04(9) \AA^{3}, Z 2, \rho_{\text {calcd }}$ $1.895 \mathrm{Mg} \mathrm{m}^{-3}, \lambda 0.71073 \AA$ А $\mu 7.504 \mathrm{~mm}^{-1}$, reflections collected 67453 , independent reflections 29220 [R(int) $=0.0347]$, max./min. transmission 0.203/0.064, data/restraints/parameters: 29 220/1/646. GoF 0.906. Final $R$ indices $[I>2 \sigma(I)]: R_{1}=$ $0.0278, \mathrm{w} R_{2}=0.0519 ; R$ indices (all data): $R_{1}=0.0528, \mathrm{w} R_{2}=$ 0.0536. Largest diff. peak and hole 3.900 and -2.283 e $\AA^{-3}$.

cis-4.2Br.2MeOH. $M=1402.82$, orthorhombic, space group $C 222_{1}, a=16.5234(2), b=17.3329(2), c=33.2686(3) \AA, V$ 9528.08(18) $\AA^{3}, Z$ 8, $\rho_{\text {calcd }} 1.956 \mathrm{Mg} \mathrm{m} \mathrm{m}^{-3}, \lambda 0.71073 \AA, \mu$ $7.882 \mathrm{~mm}^{-1}$, reflections collected 109454, independent reflections $23678[R(\mathrm{int})=0.0623]$, max./min. transmission 1.00/0.43, data/restraints/parameters: $23678 / 122 / 653$. GoF 0.846. Final $R$ indices $[I>2 \sigma(I)]: R_{1}=0.0316, \mathrm{w} R_{2}=0.0524$; $R$ indices (all data): $R_{1}=0.0583, \mathrm{w}_{2}=0.0576$. Absolute structure parameter: $-0.043(4)$. Largest diff. peak and hole 2.859 and $-1.526 \mathrm{e}^{-3}$. The atoms of one $\mathrm{C}_{4}$ chain were modelled as being disordered over two sets of sites with occupancies refined to $0.708(3)$ and its complement. The solvent was modelled as two $\mathrm{MeOH}$ molecules, both disordered over two sets of sites with occupancies constrained, after trial refinement, to be the same as those of the disordered $\mathrm{C}_{4}$ chain.

trans $\mathbf{4} \cdot \mathbf{2 B r} \cdot 3 \mathrm{MeOH} . M=1434.86$, monoclinic, space group $P 2_{1} / n, a=12.6255(3), b=27.8969(7), c=15.7022(4) \AA, \beta=$ 107.297(3) ${ }^{\circ}, V$ 5280.4(2) $\AA^{3}, Z 4, \rho_{\text {calcd }} 1.805 \mathrm{Mg} \mathrm{m} \mathrm{m}^{-3}, \lambda$ $0.71073 \AA$ А $\mu 7.115 \mathrm{~mm}^{-1}$, reflections collected 49310 , independent reflections $9275[R(\mathrm{int})=0.0751]$, max. $/ \mathrm{min}$. transmission 1.00/0.72, data/restraints/parameters 9275/537/703. GoF 1.223. Final $R$ indices $[I>2 \sigma(I)]: R_{1}=0.0954, \mathrm{w} R_{2}=0.1958 ; R$ indices (all data): $R_{1}=0.1504, \mathrm{w} R_{2}=0.2095$. Largest diff. peak and

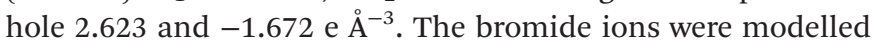
as being disordered over 5 sites with the sum of their occupancy factors constrained to be 2 . The other remaining peaks were modelled as three methanol solvent molecules. The central atoms of the $\mathrm{C}_{4}$ alkyl chains were modelled as being disordered over two sets of sites with occupancies set at 0.5 after trial refinement. 


\section{Measurement of lipophilicity}

The octanol-water partition coefficients $(\log P)$ of $c i s-\mathbf{1} \cdot 2 \mathrm{Br}$, cis$2 \cdot 2 \mathrm{Br}$, cis-3.2Br and $c i s-\mathbf{4} \cdot 2 \mathrm{Br}$ were determined using the shakeflask method. ${ }^{43}$ Water (50 mL, milli-Q purification) and $n$-octanol (vacuum distilled) were shaken together using a laboratory shaker (Mistral Multi-Mixer) for $72 \mathrm{~h}$ to allow saturation of both phases. Stock solutions of the $\mathrm{Au}$ compounds $(40 \mu \mathrm{M})$ were prepared in the aqueous phase and aliquots $(1 \mathrm{~mL})$ of each stock solution were then added to an equal volume of the $n$-octanol phase. The resultant solutions containing two phases were mixed for $1 \mathrm{~h}$ and following a short incubation at $37^{\circ} \mathrm{C}$ were centrifuged $(3000 \mathrm{~g}, 5 \mathrm{~min}$, Eppendorf Centrifuge $5415 \mathrm{C}$ ) to separate the phases. The concentrations of the Au complexes in the organic and aqueous phases were determined using their UV absorbance $(310 \mathrm{~nm}, 288 \mathrm{~nm}$, $259 \mathrm{~nm}$, and $315 \mathrm{~nm}$, respectively for cis-1.2Br, cis-2.2Br, cis$3 \cdot 2 \mathrm{Br}$ and cis-4.2Br). $\log P$ was defined as the logarithm of the ratio of the concentrations of each of the complexes in the organic and aqueous phases $\left(\log P=\log \left(\left[\mathrm{Au}_{\mathrm{org}}\right] /\left[\mathrm{Au}_{\mathrm{aq}}\right]\right)\right.$; values reported are the means of three separate determinations).

\section{Spectroscopy}

Electronic absorption spectra were recorded on a Perkin Elmer Lambda 25 UV-Vis spectrometer, and luminescence excitation and emission spectra were recorded on a Varian Cary Eclipse Luminescence Spectrometer. The emission quantum yield $(\Phi)$ of cis-3.2Br was determined using standard procedures with respect to the quantum yield of a reference $\left(\Phi_{\mathrm{R}}\right)$ according to eqn (1): ${ }^{42,56}$

$$
\Phi=\Phi_{\mathrm{R}} \frac{I}{I_{\mathrm{R}}} \frac{n^{2}}{n_{\mathrm{R}}{ }^{2}}
$$

where $I$ is the gradient of the standard curve of absorbance $v s$. integrated emission intensity for cis-3.2Br, $I_{\mathrm{R}}$ is the gradient of the standard curve of absorbance vs. integrated emission intensity for the reference solution, $n$ is the refractive index of the solution and the subscript $R$ refers to the reference fluorophore of known quantum yield. The reference used was quinine sulfate (Alfa Aesar, 98\%), dissolved in $0.1 \mathrm{M} \mathrm{H}_{2} \mathrm{SO}_{4}$, and having $\Phi_{\mathrm{R}}=0.577\left(T=22{ }^{\circ} \mathrm{C}\right) .{ }^{41,42}$ Measurements were made using two excitation wavelengths, $\lambda_{\mathrm{ex}}=288$ and $345 \mathrm{~nm}$.

\section{Cell culture}

Human cervical cancer (HeLa, ATCC) cells were cultured at $37{ }^{\circ} \mathrm{C}$ under humidified 95\% air/5\% $\mathrm{CO}_{2}$ in Dulbecco's modified Eagle's medium (DMEM) without phenol red, containing Earle's balanced salt solution and supplemented with $2 \mathrm{mM}$ GlutaMAX, penicillin (100 $\left.\mathrm{U} \mathrm{mL}^{-1}\right)$, streptomycin $(100 \mathrm{mg}$ $\mathrm{mL}^{-1}$ ) and $10 \%$ heat inactivated foetal calf serum (FCS). MDA-MB-231 human breast adenocarcinoma cells (MDA, ATCC, kindly donated by Prof. A. Dharmarajan, School of Anatomy and Human Biology, University of Western Australia) were cultured at $37{ }^{\circ} \mathrm{C}$ under humidified $95 \%$ air $/ 5 \% \mathrm{CO}_{2}$ in RPMI 1640 GlutaMAX (Gibco/Invitrogen), supplemented with $10 \%$ foetal bovine serum, penicillin $\mathrm{G}$ sodium $\left(10^{3}\right.$ units per
$\mathrm{mL})$, streptomycin sulfate $\left(10 \mathrm{mg} \mathrm{mL}^{-1}\right)$ and amphotericin $\mathrm{B}$ $\left(25 \mu \mathrm{g} \mathrm{mL}{ }^{-1}\right)$. Both cell lines were passaged every 3-5 days.

\section{Cell proliferation/viability}

HeLa cells grown in 96 well plates were incubated for $24 \mathrm{~h}$ in $200 \mu \mathrm{L}$ of their growth medium containing increasing concentrations of cis-1.2Br, trans-1.2Br, cis-3.2Br or trans-3.2Br. Cell viability was determined using a cell titer assay following the manufacturer's instructions (Promega, G3580). The assay was performed by adding $7 \mu \mathrm{L}$ of the CellTiter $96 \AA$ Aqueous One Solution Reagent (MTS assay) directly to the culture wells, incubating for $1 \mathrm{~h}$, and then recording the absorbance at $490 \mathrm{~nm}$ in a BMG Labtech Fluostar Optima plate reader. The data are expressed as percent of cells grown in the absence of any $\mathrm{Au}$ complexes. Data are means $\pm \mathrm{SD}$ of three independent experiments.

\section{Luminescence microscopy of live MDA cells}

MDA cells were grown in a $2.5 \mathrm{~mL}$ culture chamber for $24 \mathrm{~h}$ in RPMI 1640 phenol red free medium (Gibco/Invitrogen) with no antibiotics or foetal calf serum. A stock solution of cis-3.2Br ( $1 \mathrm{mg}$ in $5 \mathrm{~mL}$ DMSO) was prepared, and immediately before use, the solution was centrifuged $(3000 \mathrm{~g}, 1 \mathrm{~min})$. Immediately before imaging, the medium was removed from the cells and the cells were washed twice with PBS $(500 \mu \mathrm{L})$, before the addition of fresh medium $(1 \mathrm{~mL})$ and $50 \mu \mathrm{L}$ of the above cis$3 \cdot 2 \mathrm{Br}$ solution. The cells were viewed on a Nikon Eclipse TI inverted microscope using UV illumination (BP filter 340-380 nm), and images collected on a Coolsnap EZ digital camera (Roper Scientific) every $30 \mathrm{~s}$ for a period of $6 \mathrm{~h}$ (emission LP $425 \mathrm{~nm}$ ). NIS Elements AR software was used to convert the images in Quicktime movie format. Final cis-3·2Br concentration was determined using the extinction coefficient for absorbance at $290 \mathrm{~nm}\left(\varepsilon=22000\right.$, determined using a $2.12 \times 10^{-5} \mathrm{M}$ solution of cis-3.2Br in DMSO), to give final concentration of $0.55 \mathrm{mM}$ stock, and $26.2 \mu \mathrm{M}$ cis-3·2Br exposed to the cells.

\section{Acknowledgements}

We thank the Australian Research Council for financial support (DP0452327 to S. J. B.-P. and M. V. B. and DP0986318 to S. J. B.-P. and A. F.) and an Australian Postgraduate Award (to L. E. W.). A. F. is a National Health and Medical Research Council Senior Research Fellow. We also thank Professor Luis Filgeuira, for donation of MDA cells and access to some laboratory facilities. We acknowledge the Centre of Microscopy, Characterisation and Analysis, The University of Western Australia (a facility funded by The University of Western Australia, the Australian Government and the State Government of Western Australia) for providing access to facilities, and for scientific and technical assistance. Use of the ChemMatCARS Sector 15 at the Advanced Photon Source, for $\mathbf{I} \cdot 2 \mathrm{Br} \cdot 2 \mathrm{H}_{2} \mathrm{O}$, was supported by the Australian Synchrotron Research Program, which is funded by the Commonwealth of Australia under the Major National Research Facilities Program. 
$1 \quad$ Notes and references 2001, 2861-2868. 9340-9352. 333-354. 82, 53-69. Chem., 2010, 24, 267-300. 300-317. Chem., 2006, 3988-3996. 1276-1278. Soc., 2005, 127, 2285-2291. 82, 71-78.
1 P. Cabildo, D. Sanz, R. M. Claramunt, S. A. Bourne, I. Alkorta and J. Elguero, Tetrahedron, 1999, 55, 2327-2340.

2 I. Bitter, Z. Török, V. Csokai, A. Grün, B. Balázs, G. Tóth, G. M. Keserú, Z. Kovári and M. Czugler, Eur. J. Org. Chem.,

3 M. V. Baker, M. J. Bosnich, D. H. Brown, L. T. Byrne, V. J. Hesler, B. W. Skelton, A. H. White and C. C. Williams, J. Org. Chem., 2004, 69, 7640-7652.

4 M. V. Baker, D. H. Brown, C. H. Heath, B. W. Skelton, A. H. White and C. C. Williams, J. Org. Chem., 2008, 73,

5 M. V. Baker and D. H. Brown, Mini-Rev. Org. Chem., 2006, 3,

6 V. J. Hesler, B. W. Skelton, A. H. White, D. H. Brown and M. V. Baker, J. Inclusion Phenom. Macrocyclic Chem., 2015,

7 E. Alcalde, I. Dinarès and N. Mesquida, Top. Heterocycl.

8 S. Ramos, E. Alcalde, J. Fraser Stoddart, A. J. P. White, D. J. Williams and L. Perez-Garcia, New J. Chem., 2009, 33,

9 E. Alcalde, N. Mesquida and L. Perez-Garcia, Eur. J. Org.

10 E. Alcalde, N. Mesquida, M. Vilaseca, C. Alvarez-Rua and S. Garcia-Granda, Supramol. Chem., 2007, 19, 501-509.

11 M. V. Baker, B. W. Skelton, A. H. White and C. C. Williams, J. Chem. Soc., Dalton Trans., 2001, 111-120.

12 M. V. Baker, B. W. Skelton, A. H. White and C. C. Williams, Organometallics, 2002, 21, 2674-2678.

13 P. J. Barnard, M. V. Baker, S. J. Berners-Price, B. W. Skelton and A. H. White, Dalton Trans., 2004, 1034-1047.

14 E. Alcalde, R. M. Ceder, C. Lopez, N. Mesquida, G. Muller and S. Rodriguez, Dalton Trans., 2007, 2696-2706.

15 S. Durmus, J. C. Garrison, M. J. Panzner, C. A. Tessier and W. J. Youngs, Tetrahedron, 2004, 61, 97-101.

16 J. C. Garrison, R. S. Simons, W. G. Kofron, C. A. Tessier and W. J. Youngs, Chem. Commun., 2001, 1780-1781.

17 J. C. Garrison, R. S. Simons, J. M. Talley, C. Wesdemiotis, C. A. Tessier and W. J. Youngs, Organometallics, 2001, 20,

18 J. C. Garrison, R. S. Simons, C. A. Tessier and W. J. Youngs, J. Organomet. Chem., 2003, 673, 1-4.

19 A. Melaiye, Z. Sun, K. Hindi, A. Milsted, D. Ely, D. H. Reneker, C. A. Tessier and W. J. Youngs, J. Am. Chem.

20 R. S. Simons, J. C. Garrison, W. G. Kofron, C. A. Tessier and W. J. Youngs, Tetrahedron Lett., 2002, 43, 3423-3425.

21 V. J. Hesler, B. W. Skelton, A. H. White, D. H. Brown and M. V. Baker, J. Inclusion Phenom. Macrocyclic Chem., 2015,

22 W. Liu and R. Gust, Chem. Soc. Rev., 2013, 42, 755773.

23 L. Oehninger, R. Rubbiani and I. Ott, Dalton Trans., 2013, 42, 3269-3284.
24 J. L. Hickey, R. A. Ruhayel, P. J. Barnard, M. V. Baker, S. J. Berners-Price and A. Filipovska, J. Am. Chem. Soc., 2008, 130, 12570-12571.

25 O. Rackham, A.-M. J. Shearwood, E. Thyer, E. McNamara, S. M. K. Davies, B. A. Callus, A. Miranda-Vizuete, S. J. Berners-Price, Q. Cheng, E. S. J. Arner and A. Filipovska, Free Radicals Biol. Med., 2010, 50, 689-699.

26 P. J. Barnard, M. V. Baker, S. J. Berners-Price and D. A. Day, J. Inorg. Biochem., 2004, 98, 1642-1647.

27 P. J. Barnard, L. E. Wedlock, M. V. Baker, S. J. BernersPrice, D. A. Joyce, B. W. Skelton and J. H. Steer, Angew. Chem., Int. Ed., 2006, 45, 5966-5970.

28 H. Schmidbaur, Gold Bull., 1990, 23, 11-21.

29 H. Schmidbaur, Gold Bull., 2000, 33, 3-10.

30 H. Schmidbaur and A. Schier, Chem. Soc. Rev., 2008, 37, 1931-1951.

31 H. Schmidbaur, Chem. Soc. Rev., 1995, 24, 391-400.

32 P. Pyykko, Chem. Soc. Rev., 2008, 37, 1967-1997.

33 V. W.-W. Yam and E. C.-C. Cheng, Chem. Soc. Rev., 2008, 37, 1806-1813.

34 V. W.-W. Yam and E. C.-C. Cheng, Top. Curr. Chem., 2007, 281, 269-309.

35 A. Vogler and H. Kunkely, Coord. Chem. Rev., 2001, 219-221, 489-507.

36 M. Ferrer, A. Gutiérrez, L. Rodríguez, O. Rossell, J. C. Lima, M. Font-Bardia and X. Solans, Eur. J. Inorg. Chem., 2008, 2899-2909.

37 L. Rodríguez, M. Ferrer, R. Crehuet, J. Anglada and J. C. Lima, Inorg. Chem., 2012, 51, 7636-7641.

38 L. E. Wedlock, J. B. Aitken, S. J. Berners-Price and P. J. Barnard, Dalton Trans., 2013, 42, 1259-1266.

39 M. V. Baker, D. H. Brown, R. A. Haque, B. W. Skelton and A. H. White, Dalton Trans., 2004, 3756-3764.

40 M. V. Baker, D. H. Brown, R. A. Haque, P. V. Simpson, B. W. Skelton, A. H. White and C. C. Williams, Organometallics, 2009, 28, 3793-3803.

41 J. W. Eastman, Photochem. Photobiol., 1967, 6, 55-72.

42 F. R. Lakowicz, Principles of Fluorescence Spectroscopy, Kluwer Academic/Plenum Publishers, New York, 2nd edn, 1999.

43 A. Albert, The Physiochemical Basis of Therapy, Chapman and Hall, London, 1979.

44 D. Parker, Aust. J. Chem., 2011, 64, 239-243.

45 J. Lemke, A. Pinto, P. Niehoff, V. Vasylyeva and N. MetzlerNolte, Dalton Trans., 2009, 7063-7070.

46 S. D. Köster, H. Alborzinia, S. Can, I. Kitanovic, S. Wölfl, R. Rubbiani, I. Ott, P. Riesterer, A. Prokop, K. Merza and N. Metzler-Nolte, Chem. Sci., 2012, 3, 2062-2072.

47 H. E. Gottlieb, V. Kotlyar and A. Nudelman, J. Org. Chem., 1997, 62, 7512-7515.

48 D. D. Perrin, W. L. F. Armarego and D. R. Perrin, Purification of Laboratory Chemicals, Pergamon Press Ltd, 2nd edn, 1980.

49 E. F. M. Stephenson, Org. Synth., 1954, 34, 100-102.

50 L. P. Wu, Y. Yamagiwa, T. Kuroda-Sowa, T. Kamikawa and M. Munakata, Inorg. Chim. Acta, 1997, 256, 155-159. 
51 M. Luo, S. Guo, C. Zhou and R. Xie, Heterocycles, 1995, 41, 1421-1424.

52 J.-F. Ma, J. Yang, G.-L. Zheng, L. Li and J.-F. Liu, Inorg. Chem., 2003, 42, 7531-7534.

53 Z. Shi and R. P. Thummel, J. Org. Chem., 1995, 60, 59355945.
54 M.-C. Brandys, M. C. Jennings and R. J. Puddephatt, Dalton Trans., 2000, 4601-4606.

55 G. M. Sheldrick, Acta Crystallogr., Sect. C: Cryst. Struct. Commun., 2015, 71, 3-8.

56 C. A. Parker, Photoluminescence of Solutions, Elsevier Publishing Company, Amsterdam, 1st edn, 1968. 